Parte I - O Direito comparado e seus Protagonistas: QuAL uso, PARA QUAL FIM, COM QUAIS MÉTODOS? .....................................................................1

EDITORIAL ............................................................................................................... 3

"Tudo o que precisamos fazer é ter certeza de que continuaremos conversando".............................. 3

Gustavo Cerqueira e Patrícia Perrone Campos Mello

Direito comparado E METOdologia $\quad$................................................... 6

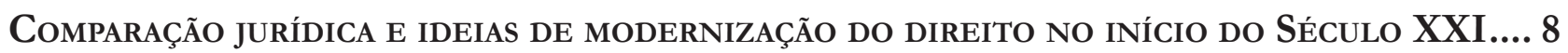
Gustavo Cerqueira

O DIREITO COMPARADO: ESFORÇO DE RESGATE HISTORIOGRÁFICO E DE PROBLEMAS METODOLÓGI$\cos$

Arnaldo Sampaio de Moraes Godoy e Gustavo Fereira Ribeiro

Direito Comparado e Política: Reflexões Necessárias .42

Raphael Carvalho de Vasconcelos e Deo Campos Dutra

Direito comparado no Brasil

L'originalité du Droit Brésilien et le Droit Comparé .57

Arnoldo Wald

LEI DA BOA RAZÃo E COMPARATISMO JURÍDICO NA DOUTRINA CIVILISTA BRASILEIRA DE 1850 A 1880

Alan Wruck Garcia Rangel

O STF EM REDE? QUANTO, COMO, COM QUE ENGAJAMENTO ARGUMENTATIVO O STF USA PRECEDENTES ESTRANGEIROS EM SUAS DECISÕES?

Patrícia Perrone Campos Mello e Felipe Meneses Graça 
Suprema Imprecisão: a metodologia em Direito Constitucional Comparado E as deficiênCias Em Seu uso pelo Supremo Tribunal Federal

Alonso Freire e Hugo Sauaia

Direitos comparados

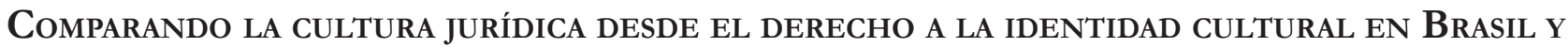

CHILE 145 Juan Jorge Faundes e Fabian Le Bonniec

O Divino e o Racional no Direito: notas para um diálogo entre sistemas jurídicos 181 Salem Hikmat Nasser e José Garcez Ghirardi

Regulação do discurso de Ódio: análise comparada em países do Sul Global 196 Jane Reis Gonçalves Pereira, Renan Medeiros de Oliveira e Carolina Saud Coutinho

Parte II - Outros temas

LA OTRA CARA DE LA MONEDA: PROTECCIÓN CONSTITUCIONAL DE LA EMPRESA, EL EMPRENDIMIENTO Y LA LIBRE COMPETENCIA EN CHILE y COLOMBiA

Juan Pablo Díaz Fuenzalida e Juan Sebastián Villamil Rodríguez

The European Court of Human Rights Decision on there 'Burqa Ban'and the CritiCal analysis of the Pragmatic experimental logic 258 Flavianne Fernanda Bitencourt Nóbrega e George Browne Rego

Direitos humanos das deslocadas ambientais e os impactos da Usina de Belo Monte: da EXPLORAÇÃO AMAZÔNICA À SUBJUGAÇÃO FEMININA

Thais Silveira Pertille e Letícia Albuquerque

Solução de Controvérsias em Acordos de Investimento: as experiênCias do CPTPP, CETA E DOS ACFIs

Fábio Morosini, Vivian Daniele Rocha Gabriel e Anastacia Costa

50 anos dos “direitos da Criança” na Convenção Americana de Direitos Humanos: a HISTÓRIA DO ARTIGO 19 311

Sven Peterke e Paloma Leite Diniz Farias 
EMPRESAS E DIREITOS HUMANOS: COMPARTILHANDO VALOR E RESPONSABILIDADES .325 Melina Girardi Fachin

CONTEMPORARY RESPONSES TO BUSINESSES' NEGATIVE HUMAN RIGHTS IMPACT 341 Andres Felipe Lopez

Human Right to LABOR PROTECTION IN UKRAINE: CURRENT SITUATION AND THE PROSPECTS OF IMPLEMENTATION OF INTERNATIONAL RULES 363 Nina Daraganova

International Regulation and Global Governance: The EU influential Method IN TIMES OF NORMATIVITY CHANGE 373 Gabriela Hühne Porto, Paula Wojcikiewicz Almeida e Juliana Maia F. A. Netto

Tecnologias digitais e o comércio de bens E SERviços na OMC/Digital. 391 Umberto Celli Junior

Los fuertes hacen lo QUe PUeden: exponiendo los límites de la Corte Penal InternaCIONAL .406

Cristián D. González-Ruiz e Víctor M. Mijares

Human Rights, Humanitarian Law and State Power 418 Renata Nagamine e João Roriz

Regional integration in the South Pacific: Challenges for Public governance .433 Joanna Siekiera

Parte III - Resenhas 443

RESENHA DA OBRA

“Democracia e policentrismo do poder", de Murilo Gaspardo 445 Angela Limongi Alvarenga Alves 


\section{Regulação do discurso de ódio: análise comparada em países do Sul Global*}

\section{Hate speech regulation: comparative analysis in Global South countries}

* Recebido em 13/02/2020 Aprovado em 21/06/2020

\footnotetext{
** Professora Associada de Direito Constitucional da Universidade do Estado do Rio de Janeiro (UERJ). Doutora em Direito Público pela UERJ. Mestre em Direito Constitucional e Teoria do Estado pela Pontifícia Universidade Católica do Rio de Janeiro (PUC-Rio). Juíza Federal. Email: janergp@gmail.com
}

*** Mestre em Direito Público e Bacharel em Direito pela Universidade do Estado do Rio de Janeiro (UERJ). Especialista em Direito Público pela Pontifícia Universidade Católica de Minas Gerais (PUC Minas). Fellow do Instituto $\mathrm{Na}$ cional de Proteção de Dados (INPD). Email: renanmedeirosdeoliveira@gmail.com

**** Bacharel em Direito pela Universidade do Estado do Rio de Janeiro (UERJ). Pesquisadora na Clínica de Direitos Fundamentais da Faculdade de Direito da UERJ - Clínica UERJ Direitos. Foi Bolsista de Iniciação Científica na Fundação de Amparo à Pesquisa do Estado do Rio de Janeiro - FAPERJ.

Email: carolina.saud@gmail.com

Agradecemos à FAPERJ pelo financiamento que contribuiu para o desenvolvimento desta pesquisa.

\author{
Jane Reis Gonçalves Pereira** \\ Renan Medeiros de Oliveira*** \\ Carolina Saud Coutinho****
}

Not Man but men inhabit this planet. Plurality is the law of the earth.

Hannah Arendt

\section{Resumo}

O objetivo deste estudo é apresentar um panorama comparativo do tratamento do discurso de ódio em diferentes países do Sul Global. Os estudos de direito comparado, em geral, analisam o tema nos Estados Unidos e em países europeus. Há uma lacuna na pesquisa do discurso de ódio nos países do Sul Global, os quais têm características históricas, políticas, sociais, culturais e econômicas semelhantes, com destaque para os elevados índices de desigualdade. Assim, foram selecionados cinco países que guardam semelhanças entre si e com o Brasil. São eles: África do Sul, Argentina, Colômbia, Índia e México. Em cada um deles, apresentamos uma breve contextualização, o modelo jurídico adotado, a jurisprudência, e uma análise crítica sobre o tratamento do tema no país. Ao final, é realizada uma reflexão sobre os desafios de enfrentamento do discurso de ódio pela via jurisdicional em países altamente desiguais e apontamos caminhos possíveis para o tratamento do tema. Para efetivar essa análise, partiremos de um conceito operacional heterogêneo de discurso de ódio, capaz de abranger diferentes tipos de manifestação de intolerância. O estudo segue metodologia de direito comparado, com foco para as abordagens classificatória e contextualista, levando em consideração, também, a abordagem funcionalista.

Palavras-Chave: Discurso de ódio; Liberdade de Expressão; Sul Global; Direito Comparado; Direito Constitucional Comparado.

\section{Abstract}

This study aims to present a comparative panorama of the treatment of hate speech in different countries of the Global South. The studies of comparative law, in general, analyze the theme in the United States and European countries. There is a gap in the research of the subject in the countries analyzed, which have similar historical, political, social, cultural, and econo- 
mic characteristics, with emphasis on the high inequality. For this, we selected five countries that have similarities between themselves and with Brazil. They are South Africa, Argentina, Colombia, India, and Mexico. In each of them, we present a brief contextualization, the legal model adopted, the jurisprudence, and a critical analysis of the treatment of the theme in the country. In the end, we reflect on the challenges of facing hate speech through the jurisdictional way in highly unequal countries, and we point out possible ways to address the issue. For this analysis, we will start from a heterogeneous operational concept of hate speech, capable of covering different types of expressions of intolerance. The study follows a comparative law methodology, focusing on the classificatory and contextualist approaches, and taking into account the functionalist approach.

Keywords: Hate Speech; Freedom of Speech; Global South; Comparative Law; Comparative Constitutional Law.

\section{Introdução'}

As manifestações de ódio são um desafio para as democracias contemporâneas. Nos últimos anos, atos motivados por intolerância religiosa ${ }^{2}$, crimes impulsionados por xenofobia ${ }^{3}$, bem como o uso das mídias sociais para incitar a violência ${ }^{4}$ tomaram conta dos noticiários de incontáveis países, trazendo o debate sobre diversidade e ódio à ordem do dia. Não raro, tais atos são escorados

\footnotetext{
1 As citações em língua estrangeira e os dispositivos constitucionais foram traduzidos livremente pelos autores.

2 V. ATTAQUES CONTRE DES lieux de culte: le chef de l'ONU appelle à lutter contre l'intolérance et la haine. ONU Info, abr. 2019. Disponível em: <https://news.un.org/fr/story/2019/04/1042221>. Acesso em: 11 jun. 2020.

3 V., HUMAN RIGHTS COUNCIL. Report of the Special Rapporteur on contemporary forms of racism, racial discrimination, xenophobia and related intolerance. A/HRC/38/52. [s.l.], abr. 2018. Disponível em: <https://documents-dds-ny.un.org/doc/ UNDOC/GEN/G18/117/79/PDF/G1811779.pdf>. Acesso em: 11 jun. 2020; LUTTE CONTRE LA haine, la discrimination, le racisme et l'antisémitisme. Ministère de L'Intérieur, feb. 2019. Disponível em: <https://www.interieur.gouv.fr/Actualites/Communiques/Lutte-contre-la-haine-la-discrimination-le-racisme-et-lantisemitisme>. Acesso em: 11 jun. 2020.

4 PEREIRA, Néli. Redes sociais validam o ódio das pessoas, diz psicanalista. BBC Brasil, São Paulo, 10 de jan. de 2017. Disponível em: <https://www.bbc.com/portuguese/brasil-38563773>https:// www.bbc.com/portuguese/brasil-38563773. Acesso em: 03 de set. de 2019.
}

em discursos - por vezes endossados até mesmo por lideranças políticas ${ }^{5}$ - que instigam ações violentas contra certos grupos. Ganha importância, assim, o debate sobre o tratamento jurídico do discurso de ódio - isto é, manifestações que estimulam intolerância, hostilidade e violência contra grupos, motivadas por preconceitos em relação ao gênero, raça, etnia, religião, orientação sexual, deficiência, dentre outros fatores ${ }^{6}-\mathrm{e}$ os limites da liberdade de expressão.

A discussão tem relevância global, sobretudo em regimes democráticos. A necessidade de assegurar aos cidadãos a possibilidade de expressar seu pensamento livremente, seja para participar da vida pública, seja para manifestações em espaços privados, entra em choque com outros valores protegidos pelo constitucionalismo contemporâneo, com destaque para a igualdade e a dignidade humana. Diante desse conflito, fala-se em dar predominância à liberdade de expressão, protegendo a livre manifestação em todas as circunstâncias, ou, na linha oposta, em interditar discursos que incitem à violência motivada por discriminação. A dimensão global do tema fica clara pela edição de tratados e documentos internacionais ${ }^{7-8}$ buscando trazer linhas gerais sobre $\mathrm{O}$ tratamento a ser dado à liberdade de expressão, ao combate à discriminação e ao discurso de ódio.

A solução específica, contudo, pode variar consideravelmente de acordo com as particularidades de cada

5 ARTICLE 19. Responding to 'hate speech': Comparative overview of six EU countries. London: Article 19, 2018, p. 5.

${ }^{6} \mathrm{O}$ conceito será explorado com mais detalhes no item 1 deste estudo.

7 Em geral, os tratados protegem diretamente a liberdade de expressão, e, em alguns casos, trazem recomendações específicas para combater o discurso de ódio. Muitas vezes, também estabelecem proteção especial contra a discriminação. V., por exemplo, art. $4^{\circ}$ da Convenção Internacional sobre a Eliminação de Todas as Formas de Discriminação Racial, de 1965; art. 13 da Convenção Americana sobre Direitos Humanos, de 1969; arts. 2 , 19, 20, 26 e 27 do Pacto de Direitos Civis e Políticos, de 1966; art. 20 do Plano de Ação de Rabat, de 2012, desenvolvido pelo Gabinete do Alto Comissariado para os Direitos Humanos (OHCHR) em conjunto com especialistas; Resolução nº 16/18 (Combatendo a intolerância, estereótipos negativos e estigmatização, discriminação e incitação à violência contra pessoas com base em religião ou crença), adotada pelo Conselho de Direitos Humanos da ONU (CDH) em 2011.

${ }^{8}$ Esses documentos também geram debates doutrinários. Stefan Kircher, por exemplo, analisa se a previsão da liberdade de expressão e do discurso de ódio na Convenção Europeia de Direitos Humanos configura limitação inerente daquela liberdade. KIRCHNER, Stefan. Outlawing hate speech in democratic States: the case against the inherent limitations doctrine concerning Article 10 (1) of the European Convention on Human Rights. Revista de Direito Internacional, Brasília, v. 12, n. 1, p. 415-423, 2015. 
região e de cada país, já que alguns desafios são globais e comuns a todos os países e outros são locais e singulares. Há muitos trabalhos investigando o discurso de ódio sob a perspectiva comparada, mas eles se limitam, em geral, a analisar o tema nos Estados Unidos e em países europeus. Isso se deve, em grande medida, ao fato de que o debate nos termos em que conhecemos foi moldado nesses países, que funcionaram como ponto de inspiração para outros ordenamentos jurídicos?.

Há, contudo, uma lacuna na pesquisa e comparação do tratamento desse tema em países do Sul Global. Eles têm características históricas, políticas, sociais, culturais e econômicas que os distinguem dos países tradicionalmente estudados, bem como guardam importantes semelhanças entre si, com destaque para os índices de desigualdade. Nesse contexto, o estudo comparado tende a ser proveitoso, e a migração de ideias constitucionais encontra campo fértil. Nossa intenção, assim, é contribuir para a análise comparativa do discurso de ódio nos países desse eixo.

Mesmo sendo um tema tão antigo quanto a própria humanidade $^{10}$, foi apenas após a segunda Guerra Mundial que passou a existir debate teórico sistematizado e resposta jurisprudencial ao discurso de ódio. A sua importância, contudo, tende a variar de acordo com o modelo democrático adotado e o regime de direitos fundamentais. No atual contexto mundial, em que entram pauta a crise da democracia ${ }^{11}$ e as recessões democráti$\mathrm{cas}^{12}$, e em que as manifestações de ódio se intensificam - sobretudo com o uso da internet ${ }^{13}$-, a importância de

\footnotetext{
9 BELAVUSAU, Uladzislau. Hate Speech. In: Max Planck Encyclopedia of Comparative Constitutional Law [MPECCoL], 2017, p. 1. Disponível em: <https://oxcon.ouplaw.com/view/10.1093/ law-mpeccol/law-mpeccol-e130?prd=MPECCOL $>$. Acesso em: 07 jan. 2020 e ROSENFELD, Michel. Hate speech in constitutional jurisprudence: a comparative analysis. Cardozo Law School, working paper series n. 41, p. 4, 2001. Disponível em: <http://papers. ssrn.com/paper.taf?abstract_id=265939>. Acesso em: 8 jan. 2020.

10 BELAVUSAU, Uladzislau. Op. cit.

11 V., por todos, LEVITSKY, Steven; ZIBLATT, Daniel. How democracies die. New York: Crown, 2018; RUNCIMAN, David. How Democracy Ends. Nova York: Basic Books, 2018; CASTELLS, Manuel. Rupture: the crisis of liberal democracy. Cambridge, UK: Polity Press, 2018.

12 De acordo com o Larry Diamond, nos últimos 15 anos, mais de $20 \%$ das democracias falharam. Cf. DIAMOND, Larry. Facing Up to the Democratic Recession. Journal of Democracy, Whashington, v. 26, n.1, p. 141-155, jan. 2015.

13 A internet tem esse potencial tanto pela possibilidade de criar perfis anônimos aparentemente impunes, o que deixa as pessoas confortáveis para se manifestarem de forma discriminatória e incitando ódio, quanto pelo seu funcionamento na era dos algoritmos.
}

proteger a liberdade de expressão, os direitos de minorias $^{14}$ e a dignidade humana volta ao centro das preocupações.

Nesse panorama, as diferentes maneiras de proteger a liberdade de expressão e garantir respeito e integridade de grupos vulneráveis ao discurso de ódio merecem ser investigadas com o recurso ao direito comparado. Pesquisadores comparatistas costumam apontar três grandes propósitos dessa metodologia ${ }^{15}$ : em primeiro lugar, melhorar a compreensão do próprio sistema jurídico, pois a análise comparada traria como consequência uma reflexão sobre as normas e soluções nacionalmente adotadas; em segundo, ela tem uma utilidade prática no plano doméstico, já que o conjunto normativo estrangeiro pode ser usado como fonte de inspiração para o legislador e para o juiz; e, por fim, pode ser aproveitada no plano internacional, pois juízes que decidem com base no direito internacional teriam a possibilidade de harmonizar as respostas legais aos casos $\operatorname{concretos}^{16}$.

No estudo do direito constitucional comparado, a literatura enumera diversos tipos de abordagem meto-

Os mecanismos de filtragem de websites reforçam preconceitos e o isolamento dos indivíduos, o que significa que a personalização da informação por meio do funcionamento dos algoritmos colabora para selecionar apenas as mensagens consistentes com as predisposições e crenças do usuário. Isso contribui para a formação do que Cass Sunstein chama de echo chambers, ou seja, um sistema fechado que não permite a livre circulação de ideias ou conceitos alternativos. No Brasil, essa noção ficou conhecida pela expressão filtros-bolha. A ideia subjacente é a de que a falta de contato com opiniões divergentes leva à polarização do discurso e a radicalismos. Cf. SUNSTEIN, Cass R. \#Republic: Divided Democracy in the Age of Social Media. Princeton: Princeton University Press, 2017.

${ }^{14}$ No presente estudo, a ideia de minorias é adotada sob a perspectiva política, buscando designar grupos - definidos com base em critérios de etnia, raça, gênero, orientação sexual e culturais - subrepresentados nos espaços de decisão estatal. O termo não é necessariamente coincidente com a composição numérica do grupo (maioria e minoria sob o aspecto quantitativo). Para uma discussão sobre a evolução do conceito sociológico de minoria, cf. WIRTH, Louis. The problem of minority groups. In: LINTON, R. (Ed.). The science of man in the world crisis. New York: Columbia University Press, p. 347-372; KILLIAN, L. M. What or who is a "minority"? Michigan Sociological Review, v. 10, p. 18-31, 1996; AMERSFOORT, Hans van. 'Minority' as a sociological concept. Ethnic and Racial Studies, v. 1, n. 2, p. 218-234, 1978.

15 Cf. SIEMS, Mathias. Comparative Law. Cambridge: Cambridge University Press, 2014, p. 2-5.

${ }^{16}$ Cf. FREIRE, Alonso Reis Siqueira. A comparação no direito constitucional: metodologias, abordagens, tipos de pesquisa $\mathrm{e}$ princípios de inferência orientada para pesquisas small-n. 2014. 52f. Universidade do Estado do Rio de Janeiro, Rio de Janeiro, 2014, mimeo. 
dológica ${ }^{17}$. No presente artigo, nos valeremos dos enfoques classificatório, pois buscaremos dividir o objeto de pesquisa em categorias, e contextualista, uma vez que consideramos que o contexto social e cultural de um país influencia decisivamente o desenvolvimento de seus regimes jurídicos. Afinal, como afirma Ran Hirschl, o direito é uma construção cultural e complexa, e as normas de uma comunidade refletem suas aspirações ${ }^{18}$. Aspectos da teoria funcionalista também serão levados em conta, uma vez que avaliamos criticamente as maneiras de lidar com o discurso de ódio nos países analisados. Essa abordagem parte do pressuposto de que os países muitas vezes enfrentam dificuldades similares, de modo que seria possível comparar o tratamento conferido em cada um deles e eleger o mais eficaz sob o ângulo normativo. Tal premissa tende a ser julgada como falha e receber muitas críticas da doutrina, entendimento ao qual nos filiamos, uma vez que aspectos culturais e históricos subjacentes a cada sistema jurídico influenciam no tratamento a ser conferido pelo ordenamento jurídico e em sua eventual (in)efetividade. Nada obstante, é possível utilizá-la de forma proveitosa quando conjugada com o método contextual. É o que fazemos neste estudo. Analisamos o tratamento dado ao discurso de ódio em países do Sul Global - uma vez que guardam semelhanças -, mas buscamos apenas destacar quais mecanismos têm sido funcionais em cada contexto, sem pretender eleger respostas únicas ou de-

\footnotetext{
17 Vicki Jackson divide essas abordagens em cinco categorias complementares: i) classificatória, pela qual os objetos de pesquisa são divididos em classes, de modo a oferecer uma compreensão mais ordenada dos resultados. Por exemplo, o agrupamento dos diferentes sistemas jurídicos nas famílias de civil law e common law e os modelos de controle de constitucionalidade concentrado e difuso; ii) históri$\mathrm{ca}$, que se destina a entender o desenvolvimento do direito constitucional ao longo do tempo, o que envolve o estudo da origem e das razões do surgimento de determinado instituto; iii) universalista, cujo objetivo é, nas palavras de Donald Komers, buscar "princípios de justiça e obrigação política que transcendem as opiniões e convenções ligadas à cultura de uma comunidade política em particular" (KOMMERS, Donald P. The Value of Comparative Constitutional Law. John Marshall Journal of Practice and Procedure, Chicago, v. 9, p. 685-695, 1976); iv) funcionalista, que busca a forma mais eficiente de lidar com determinada situação-problema; e v) contextual, pelo qual o contexto social e cultural de cada nação influencia no desenvolvimento de seus aspectos jurídicos. JACKSON, Vicki C. Comparative Constitutional Law: Methodologies. In: ROSENFELD, Michel; SAJÓ, András (eds.). The Oxford Handbook of Constitutional Comparative Law. Oxford: Oxford University Press, 2012, p. 62 e ss.

18 HIRSCHL, Ran. Comparative Matters: The Renaisssance of Comparative Constitutional Law. Oxford: Oxford University Press, 2014, p. 198.
}

finitivas ou construir modelos ideais.

É que, mesmo a partir de uma análise comparativa entre países com diversas semelhanças, o debate sobre importação de ideias constitucionais deve ser travado com prudência. Os conceitos e as compreensões de Estados estrangeiros podem ser úteis, mas devem passar por uma filtragem crítica, sendo assimilados apenas no que esteja de acordo com a sistematicidade do ordenamento $^{19}$.

Na primeira parte do artigo são abordadas as principais premissas teóricas e os conceitos operacionais aqui adotados. Inicialmente, explicamos a definição e a abrangência da categoria Sul Global, criada após o fim da Guerra Fria buscando dividir o mundo não mais entre Leste e Oeste, mas entre Norte, que representaria os países desenvolvidos, e o Sul, abrangendo países em desenvolvimento. Em sequência, explicamos brevemente a importância e a fundamentação da liberdade de expressão em um regime democrático para, em seguida, fazer uma delimitação do conceito de discurso de ódio aqui empregado, o qual, adianta-se, é construído de forma ampla o suficiente para abranger diferentes manifestações de ódio em países distintos. Ainda nesse tópico, pontuamos como o ordenamento jurídico pode lidar com o discurso de ódio. Nesse sentido, identificamos dois principais modelos: de um lado, há países que adotam apenas medidas repressivas, prevendo proibições abstratas ao discurso de ódio; de outro, há os que preveem medidas alternativas, contemplando políticas públicas de combate à intolerância.

Na segunda parte são estudados cinco países do Sul Global e é exposto o cenário do discurso de ódio em cada um. As análises individuais partem de uma breve investigação contextual, para identificar fatores políticos e sociais influentes no debate; expõem o modelo jurídico, se repressivo ou alternativo; apresentam as principais decisões jurisprudenciais sobre o tema, quando existentes; e são finalizadas com uma breve análise crítica daquele modelo.

$\mathrm{Na}$ terceira e última parte é feita uma avaliação crítica

19 Discutindo a noção de migração de ideias constitucionais e pontuando os riscos e consequências de transplantes legais, cf. FRANKENBERG, Günter. Constitutional transfer: the IKEA theory revisited. I-CON, v. 8, n. 3, p. 563-579, 2010; FRANKENBERG, Günter (Ed.). Order from transfer: comparative constitutional design and legal culture. Cheltenham, UK; Northampton, MA, USA: Edward Elgar, 2013; CHOUDHRY, Sujit (Ed.). The migration of constitutional ideas. Cambridge: Cambridge University Press, 2006. 
do uso de mecanismos judiciais de combate ao ódio em países altamente desiguais, como são os do Sul Global. Emular conflitos e respostas de países do Norte, em muitos contextos, mostra-se contraproducente ${ }^{20}$. É relevante refletir sobre soluções específicas para o cenário nacional, aproveitando a experiência de países vizinhos e similares e importando ideias de forma responsável e adaptada.

\section{Premissas teóricas}

A ideia de Sul Global tem sido adotada de modo crescente nos estudos de ciência política, sociologia e antropologia, e diz respeito a países marcados por uma estrutura social e econômica com extremas desigualdades. O conceito surge como uma crítica à forma como o conhecimento era produzido, apenas com uma apropriação de teorias norte-americanas e europeias, e ao modo como o saber inovador do Sul era tido como inexistente e apropriado pela cultura do capitalismo colonial $^{21-22}$. Remete à nova separação internacional surgida no pós-Guerra Fria, em que o mundo não mais seria dividido entre Leste (países comunistas) e Oeste (países capitalistas), mas entre Norte (países desenvolvidos, industrializados no século XIX) e Sul (países em desenvolvimento, ex-colônias e de industrialização tardia). Tendo em vista que tudo o que era produzido no Sul era visto como "inexistente" e, portanto, "excluído de forma radical porque permanece exterior ao universo que a própria concepção de inclusão considera como o 'outro"'23, essa nova divisão seria criada para "reparar os danos e impactos historicamente causados pelo

\footnotetext{
${ }^{20}$ Não se ignora que em muitos campos a comparação com os modelos de inspiração para a criação de categorias no direito nacional são indispensáveis para a compreensão de respectivos temas, como, por exemplo, no campo da vinculação de precedentes, reforçado em nosso sistema nos últimos anos. Sobre o tema, cf. MELLO, Patrícia Perrone Campos. Precedentes vinculantes nos Estados Unidos da América e no direito brasileiro: um estudo comparado. Revista de Direito Internacional, Brasília, v. 13, n. 3, p. 263-285, 2016.

${ }^{21}$ MORIN, E. Para um pensamento do sul. In: Para um pensamento do Sul: diálogos com Edgar Morin. Rio de Janeiro: SESC, Dep. Nacional, 2011, p. 8-21.

22 O conceito, contudo, não é livre de críticas. Para uma análise neste sentido, cf. ROSA, Marcelo. Sociologias do Sul: ensaio bibliográfico sobre limites e perspectivas de um campo emergente. Civitas: Revista das Ciências Sociais, Porto Alegre, v. 14, n. 1, p. 43-65, jan./abr. 2014

23 SANTOS, Boaventura de Sousa. Para além do pensamento abissal: das linhas globais a uma ecologia dos saberes. Novos Estudos CEBRAP, São Paulo, n. 79, p. 71, nov. 2007.
}

capitalismo na sua relação colonial com o mundo" 24 e valorizar os conhecimentos produzidos nesses países tido como periféricos, historicamente anulados e apropriados pela colonização capitalista.

Por mais que, como destacado na introdução, o debate tal como conhecemos hoje tenha se desenvolvido nos Estados Unidos e na Alemanha, cujos modelos serviram de paradigma de inspiração para diversos países do mundo, é questionável por que, muitas vezes, o estudo sobre discurso de ódio não abrange o cenário de países do Sul Global. Nestes, o contexto fático de desigualdades reflete uma grande quantidade de manifestações de ódio, o que é solidificado pela segregação proveniente desses discursos. É urgente analisar as diversas experiências acerca do problema nessa região, e não somente as dos países do Norte, comumente considerados como principais reflexos da modernidade global.

Essa análise tende a contribuir não apenas para o debate no Brasil, mas em todos os países do Sul Global, já que eles possuem elevado grau de similaridade entre si - o que não ocorre quando se compara um país desse eixo com os Estados Unidos e/ ou com países europeus. Nessa perspectiva, a análise do tema sob a perspectiva apresentada é essencial não somente para encontrar a melhor solução considerando-se a defesa dos direitos humanos, mas também para dar o devido espaço aos conhecimentos provenientes dos povos do Sul, cuja histórica dependência política e econômica manifesta-se, principalmente, no domínio do saber.

Assim, dando sequência ao debate, a abordagem jurídica do discurso de ódio pode ser apresentada nos seguintes termos: em que medida é constitucionalmente aceitável restringir a liberdade de expressão em prol de outros valores constitucionais, como a dignidade humana e direitos fundamentais de minorias? Antes de avaliar as respostas que os países do Sul Global dão ao questionamento, cabe destacar a importância da liberdade de expressão, cuja proteção integra a espinha dorsal das democracias liberais e que é considerada o pilar das liberdades comunicativas, já que é pressuposto de direitos,

\footnotetext{
${ }^{24}$ SANTOS, Boaventura de Sousa; MENESES, Maria Paula. Introdução. In: _ _ (Orgs.). Epistemologias do Sul. Coimbra: Almedina, 2009, p. 12. V., ainda, DADOS, Nour; CONNELL, Raewyn. The global South. Contexts, v. 11, n. 1, p. 12-13, winter 2012; CONNELL, R. Southern theory: the global dynamics of knowledge in social science. Cambridge: A\&U Academic, 2007.
} 
como as liberdades de religião, de imprensa e de crença ${ }^{25}$.

A história desta liberdade confunde-se com a trajetória do constitucionalismo moderno e das lutas contra a opressão. No Brasil e em outros países do Sul Global, as experiências autoritárias cíclicas e recentes conferiram à sua proteção um forte valor simbólico e emocional. Os anos de censura institucionalizada e o fato de esses países serem democracias jovens fazem com que o tema seja de abordagem delicada, o que favorece a defesa das teses que preconizam o absenteísmo do Estado na regulação do discurso de ódio. Contudo, diferentemente dos Estados Unidos, em que vigoram ideias e premissas libertárias que levaram ao reconhecimento da liberdade de expressão como dotada de posição preferencial frente a outros direitos ${ }^{26}$, os anos de sistemática violação dos direitos fundamentais e da dignidade humana nos países do Sul Global abrem algum espaço para as ideias que buscam limitar a liberdade de expressão a fim de evitar a disseminação do ódio e da potencial violência.

No plano jurídico, a liberdade de expressão compreende uma dimensão negativa, de abstenção do Estado em restringir a difusão de ideias, e outra de caráter positivo, voltada à promoção do debate e transmissão de informações ${ }^{27}$. Quanto à fundamentação filosófica, ela se justifica de forma autônoma pela estreita conexão com a autonomia existencial. A possibilidade de exprimir ideias e se comunicar é uma necessidade humana, manifestação da individualidade intrínseca à dignidade. Além disso, o direito à liberdade de expressão é justi-

${ }^{25}$ Cf. MACHADO, Jónatas Eduardo Mendes. Liberdade de expressão: dimensões constitucionais da esfera pública no sistema social. Coimbra: Coimbra Editora, 2002.

26 Apesar disso, a grande margem de proteção dada à liberdade de expressão e a consequente abrangência constitucional do discurso de ódio levantam sérias críticas nos Estados Unidos. Em países como os do Sul Global, as recorrentes perseguições e violações de direitos fundamentais explicam a maior frequência de proibição do discurso de ódio. Nos Estados Unidos, contudo, também há um longo e grave histórico de violação de direitos e de exclusão de minorias, sobretudo da população negra, como destaca Michel Rosenfeld, que, por isso, pontua que a solução norte-americana é menos satisfatória do que outras alternativas existentes. ROSENFELD, Michel. Hate speech in constitutional jurisprudence: a comparative analysis. Cardozo Law School, working paper series n. 41, p. 53, 2001. Disponível em: < http://papers.ssrn. com/paper.taf?abstract_id=265939>. Acesso em: 8 jan. 2020 .

${ }^{27}$ Em outras palavras, no âmbito de proteção da liberdade de expressão deve-se atentar não somente para visão tradicional de um direito negativo de abstenção, mas também ao viés da promoção do debate e difusão de informações a partir de ações positivas do Estado. SARMENTO, Daniel. Liberdade de expressão, pluralismo e o papel promocional do Estado. Revista Diálogo Jurídico, Salvador, n. 16 , p. 28 , maio/ago. 2007. ficado por sua função instrumental, como ferramenta para promover a deliberação e fortalecer a democracia ${ }^{28}$. Muitas vezes, porém, a difusão de discursos segregacionistas e discriminatórios, que estimulam o ódio e a exclusão social de grupos de pessoas com características comuns, opera uma afronta ao direito à igualdade e aos princípios da não discriminação e da dignidade da pessoa humana, bem como corrói os pressupostos da deliberação democrática.

Com efeito, existe uma relação sinérgica entre discurso de ódio, desigualdade e discriminação, que se manifesta em duas dimensões. Primeiro, esse tipo de discurso atua como um dispositivo de manutenção e validação das desigualdades e práticas discriminatórias, por reforçar estigmas e intimidar os destinatários das mensagens ${ }^{29}$. Além disso, os contextos sociais nos quais a discriminação e desigualdade são estruturais inibem o acesso dos grupos discriminados ao debate público e ao sistema de justiça, tornando, assim, mais difícil a resposta social e jurídica ao discurso de ódio.

No entanto, é tênue a fronteira entre, de um lado, a discriminação e a incitação ao ódio, que seriam reprováveis, e, de outro, o discurso constitucionalmente protegido $^{30-31}$. A própria definição do discurso de ódio

${ }^{28}$ Sobre as fundamentações da liberdade de expressão e sua conexão com a democracia, cf. SCHAUER, Frederick. Free speech: a philosophical enquiry. New York: Cambridge University Press, 1982; PEREIRA, Jane Reis Gonçalves. Classificação indicativa e vinculação de horários na programação de TV: a força das imagens e o poder das palavras. Revista da Seção Judiciária do Rio de Janeiro, v. 20, p. 169-197, 2013; MACHADO, Jónatas Eduardo Mendes. Op. cit., 2002. V., ainda, MACHADO, Natália Paes Leme. A "plena" liberdade de expressão e os direitos humanos: análise da jurisprudência da corte interamericana de direitos humanos e o julgamento da ADPF 130. Revista de Direito Internacional, Brasília, v. 10, n. 2, p. 280-296, 2013. A autora, contudo, adota uma visão de que esta liberdade é absoluta.

${ }^{29}$ SORAL, Wiktor; BILEWICZ, Michał; Winiewski, Mikołaj. Exposure to hate speech increases prejudice through desensitization. Aggresive Behavior, p 1-11, 2017.

30 Norberto Bobbio define a discriminação como "uma diferenciação injusta ou ilegítima", pois contraria o princípio de justiça pelo qual "devem ser tratados de modo igual aqueles que são iguais" (BOBBIO, Norberto. A natureza do preconceito. In: ___ Elogio da serenidade: e outros escritos morais. Tradução de Marco Aurélio Nogueira. 2. ed. São Paulo: Editora Unesp, 2011, p. 107). Aponta três fases a partir das quais é possível identificar a discriminação, diferenciando-a do preconceito. Em um primeiro momento, existe um juízo de fato, que constata a diferença entre as pessoas; em segundo lugar, há um juízo de valor, que diz que entre os diferentes, um é melhor que o outro; e, por fim, uma fase concreta, pela qual o grupo que se considera superior se atribui o direito de suprimir o inferior. Cf. Ibidem, p. 107 e ss.).

${ }^{31}$ No sentido de que todo e qualquer discurso deve ser protegido, in- 
é controvertida. Não é nosso objetivo, aqui, traçar com precisão o conceito que consideramos mais adequado sob a perspectiva teórica. Tal tarefa desborda dos limites desse artigo, que busca, como dito, fazer uma análise comparada do tratamento dado ao tema em países do Sul Global.

Para viabilizar a comparação, partiremos de um conceito heterogêneo de discurso de ódio, abrangendo todas as manifestações de hostilidade, incitação à violência e difamação ${ }^{32}$ dirigidas grupos de pessoas identificadas por motivo de raça, gênero, orientação sexual, religião, etnia, origem nacional, deficiência, dentre outros, ou aquelas manifestações que sejam tidas como atentatórias à pacificação social e ao pluralismo. Não ignoramos que concepções amplas e heterogêneas encerram o risco de provocar ambiguidades e esvaziar o conceito. Todavia, não adotamos essa definição como um modelo ideal, mas tendo em vista a finalidade instrumental de acomodar as concepções de diversos países e permitir a análise comparativa entre eles.

No campo teórico, em geral, a demarcação do alcance do conceito é controvertida, embora seja comum a adoção de concepções dirigidas à proteção de minorias políticas e grupos vulneráveis. Jeremy Waldron, por exemplo, após apresentar definições dos ordenamentos jurídicos do Canadá, Dinamarca, Alemanha, Nova Zelândia e Reino Unido, pontua que o aspecto comum é a preocupação com "palavras que sejam deliberadamente abusivas e/ou ofensivas e/ou ameaçadoras e/ou humilhantes dirigidas a membros de minorias vulneráveis, calculadas para despertar o ódio contra elas" ${ }^{\prime 3}$. De modo similar, Uladzislau Belavusau afirma que “'discurso de ódio' consiste em comunicação verbal ou não verbal que envolve hostilidade direcionada a grupos sociais específicos, geralmente com base em raça e $\rightarrow$ etnia (racismo, xenofobia, anti-semitismo, etc.), gênero (sexismo, misoginia), orientação sexual (homofobia, transfobia), idade (ageismo), incapacidade (capaz), etc."’34. De outro lado, há autores que adotam uma

clusive o discurso de ódio, v., por todos, LEWIS, Anthony. Freedom for the Thought That We Hate: a Biography of the First Amendment. New York: Basic Books, 2008; DWORKIN, Ronald. Foreword. In: HARE, Ivan; WEINSTEIN, James (Eds.). Extreme Speech and Democracy. New York: Oxford University Press, 2009, p. v-ix.

32 A ideia de difamação de um grupo é tratada no exterior, em algumas ocasiões, com a expressão group libel. Sobre o tema, cf. WALDRON, Jeremy. The harm in hate speech. Cambridge, MA: Harvard University Press, 2012, p. 34 e ss.

33 WALDRON, Jeremy. Op. cit., p. 8-9.

34 BELAVUSAU, Uladzislau. Op. cit., p. 1. concepção mais abrangente, não limitando o alvo a minorias políticas. É o caso de Michel Rosenfeld, para quem discurso de ódio é aquele "destinado a promover o ódio com base em raça, religião, etnia ou origem nacional” 35 .

Culturas diferentes operam com premissas e objetivos distintos, de modo que o conceito de discurso de ódio varia de acordo com o contexto de cada país e com a finalidade buscada por seu ordenamento. Em outras palavras, a abrangência do conceito tende a ter significativas alterações conforme o contexto sociocultural, uma vez que a percepção sobre o impacto social do discurso é variável. Um critério mais amplo, por exemplo, tende a ser adotado em contextos em que se busca pacificação social e nas sociedades com histórico recente de violência e de transição de regimes autoritários para regimes democráticos. Assim, a adoção da definição ampla nos permite abordar decisões como a da Corte Constitucional da África do Sul, que considerou ser discurso de ódio a manifestação de um grupo de pessoas negras dirigida a um grupo de pessoas brancas - o que, em outros contextos, seria discutível ${ }^{36}-$, e também a jurisprudência da Suprema Corte da Índia, que tem um entendimento muito restritivo sobre o que configura discurso de ódio.

Por fim, no que diz respeito ao regime jurídico do discurso de ódio, é possível classificar os ordenamentos de acordo com as medidas adotadas para combatê-lo. Por meio da análise comparada, pudemos concluir que existem dois padrões normativos de tratamento do discurso de ódio recorrentes no Sul Global. Em primeiro lugar, há o modelo repressivo, que adota apenas proibições abstratas ao discurso, as quais podem estar previstas na Constituição, no Código Penal ou em leis penais acessórias. Em segundo lugar, o modelo alternativo consagra medidas não repressivas de coibição, como políticas públicas, a existência de instituições especializadas para solução da controvérsia, medidas educativas e de propaganda antidiscriminação, mecanismos de diálogo aberto, parcerias com a sociedade civil, dentre outros. Essas medidas podem ser previstas em conjunto ou não com as medidas repressivas.

\section{Análise comparada}

Neste item, apresentamos a realidade da liberdade de expressão e do discurso de ódio em cinco países do

\footnotetext{
35 ROSENFELD, Michel. Op. cit., p. 1.

36 Sobre o tema, cf. ROSENFELD, Michel. Op. cit., p. 6 e ss.
} 
Sul Global, selecionados por guardarem fortes semelhanças entre si e com o Brasil, que consistem no fato de serem periféricos, de terem tamanhos similares (com exceção da Colômbia), economia e diversidade geográfica parecidas e também considerando a quantidade e a qualidade dos dados disponíveis, o enfrentamento do problema pelo poder judiciário e a mobilização dos setores responsáveis. Com base nesses critérios, África do Sul, Argentina, Colômbia, Índia e México serão analisados. Consideramos também, na seleção, a lacuna de tratamento pela doutrina comparatista. Não analisaremos o Brasil, uma vez que há ampla bibliografia em português sobre o discurso de ódio no país ${ }^{37}$.

A análise é feita por país e em cada um são observados quatro aspectos: 1) breve contextualização, na qual abordamos aspectos sociais, econômicos, culturais e políticos que têm impacto direto no tratamento da liberdade de expressão e na compreensão do discurso de ódio. Tendo em vista que esse tipo de discurso está atrelado à discriminação e à desigualdade, este item envolve a apresentação de dados históricos e atuais sobre a desigualdade no país; 2) modelo jurídico, em que apontamos as medidas constitucionais e legais para lidar com o tema; 3) jurisprudência, tópico no qual as principais decisões das cortes constitucionais são examinadas; e 4) análise crítica, oportunidade em que enquadramos os países no modelo repressivo ou no alternativo, conforme conceituação feita no item 1 deste estudo, e avaliamos se o tratamento é predominantemente regulatório, jurisprudencial ou misto.

\section{1 África do sul}

\subsubsection{Breve contextualização}

A segregação racial na África do Sul teve como paradigma o regime do Apartheid ${ }^{\beta}$. Implementado em 1948

\footnotetext{
37 V., por todos, SARMENTO, Daniel. A Liberdade de Expressão e o Problema do 'Hate Speech'. Revista de Direito do Estado, Rio de Janeiro, v. 4, p. 53-106, out./dez. 2006; KOATZ, Rafael LorenzoFernandez. A Liberdade de Expressão e o Discurso de Incitação ao ódio (Hate Speech). 2007. Dissertação (Mestrado em Direito Público) - Universidade do Estado do Rio de Janeiro, Rio de Janeiro, 2007; OMMATI, José Emílio Medauar. Liberdade de expressão e discurso de ódio na Constituição de 1988. 4. ed. Rio de Janeiro: Jumen Juris, 2019.

38 Apesar de, antes disso, ter havido um processo de discriminação e marginalização. Cf. FEINSTEIN, Charles H. An Economic History of South Africa. Conquest, discrimination and development.
}

- momento em que, após o fim da segunda Guerra Mundial, diversos países ao redor do mundo se aproximavam de valores humanitários -, o sistema foi o período mais representativo da discriminação ao determinar o desenvolvimento separado dos diferentes grupos raciais $^{39}$. O Apartheid teve fim em 1994, mas seus efeitos são sentidos até os dias atuais.

A discriminação e a marginalização da população negra continuam marcantes no cotidiano do país. Como observa Jeremy Seekings, a raça continua a ser muito presente na África do Sul e a ser usada para distinguir papéis sociais, políticos e econômicos ${ }^{40}$. O racismo estrutural é uma das facetas da desigualdade multidimensional que permeia a conjuntura sul-africana. A profunda desigualdade socioeconômica catalisou, por exemplo, uma onda de protestos iniciada em 2015 por estudantes do ensino superior que denunciavam a exclusão causada pelas altas taxas de matrícula e inscrição nas universidades ${ }^{41}$.

Nesse panorama conflituoso, como será visto, o tratamento do discurso de ódio na África do Sul reflete a preocupação com o valor democrático do discurso em conflito com outros valores como igualdade e dignidade das minorias, sobretudo em um Estado no qual o reconhecimento das injustiças decorrentes do colonialismo e da segregação mostra-se fundamental para a construção da paz social.

\subsubsection{Modelo jurídico}

A Constituição da África do Sul protege tanto o direito à igualdade e à não discriminação ${ }^{42}$, quanto a li-

Cambridge: Cambridge University Press, 2005.

39 Uma análise detalhada sobre o regime, desde sua implementação até sua superação, pode ser conferida em DUBOW, Saul. Apartheid, 1948-1994. Oxford: Oxford University Press, 2014.

${ }^{40}$ SEEKINGS, Jeremy. The continuing salience of race: Discrimination and diversity in South Africa. Journal of Contemporary African Studies, v. 26, n. 1, p. 1-25, jan. 2008. Apesar disso, o autor aponta que, com o passar dos anos, a raça tem deixado de ser determinante em relação a (des)vantagens econômicas.

${ }^{41}$ BOSCH, Tanja. Twitter activism and youth in South Africa: the case of \#RhodesMustFall. Information, Communication \& Society, v. 20, n. 2, p. 1-12, 2016; NORDLING, Linda. Racism rife at top South African university, says report. Nature, abr. 2019. Disponível em: <https://www.nature.com/articles/d41586-01901129-2>. Acesso em: 12 jun. 2020.

42 Constituição da República África do Sul de 1996, Seção 9 (1). “Todos são iguais perante a lei e têm o direito a igual proteção e benefício da lei. (2) A igualdade inclui o gozo pleno e igual de todos os direitos e liberdades. Para promover a conquista da igualdade, po- 
berdade de expressão ${ }^{43}$, a qual é limitada expressamente na Seção 16(2) nos casos de "propaganda de guerra", "incitação à violência iminente" e "defesa de ódio baseado em raça, etnia, gênero ou religião e que envolve a incitação a causar danos". Ao mesmo tempo em que a Constituição não confere proteção ao discurso de ódio, também não o considera uma ofensa criminal ou civil, mas abre espaço para sua regulação. Nesse sentido, a Lei de Promoção da Igualdade e Prevenção da Discriminação (Desleal Act 4 of 2000), popularmente conhecida como Equality Act, proíbe especificamente o discurso do ódio em sua seção 10, trazendo uma definição mais ampla e abrangente que a constitucional:

10. (1) Sujeito à cláusula na seção 12, ninguém pode publicar, propagar, defender ou comunicar palavras baseadas em um ou mais dos motivos proibidos, contra qualquer pessoa, que possa ser razoavelmente interpretada para demonstrar uma intenção clara de: (a) ser ofensivo; (b) seja prejudicial ou incite dano; (c) promover ou propagar o ódio.

(...)

12. Ninguém pode (a) divulgar qualquer informação; (b) publicar ou exibir qualquer anúncio ou aviso, que possa ser razoavelmente interpretado ou entendido como uma intenção clara de discriminar injustamente qualquer pessoa. Um envolvimento genuíno em criatividade artística, investigação acadêmica e científica, relatórios justos e precisos no interesse público ou publicação de qualquer informação, anúncio ou aviso de acordo com a seção 16 da Constituição, não é impedido por esta seção.

A constitucionalidade da seção 10 está atualmente na ordem do dia do país. Em novembro de 2019, o Supremo Tribunal de Apelação considerou a definição de discurso de ódio do Equality Act inconstitucional, dando

dem ser adotadas medidas legislativas e outras destinadas a proteger ou promover pessoas ou categorias de pessoas desfavorecidas por discriminação injusta. (3) O Estado não pode discriminar injustamente, direta ou indiretamente, qualquer pessoa por um ou mais motivos, incluindo raça, gênero, sexo, gravidez, estado civil, origem étnica ou social, cor, orientação sexual, idade, deficiência, religião, consciência, crença, cultura, idioma e nascimento. (4) Nenhuma pessoa pode discriminar injustamente direta ou indiretamente alguém por um ou mais motivos nos termos da subseção (3). A legislação nacional deve ser promulgada para impedir ou proibir a discriminação injusta. (5) A discriminação por um ou mais dos motivos listados na subseção (3) é injusta, a menos que seja estabelecido que a discriminação é justa".

${ }^{43}$ Constituição da República África do Sul de 1996, Seção 16 “(1) Todos têm direito à liberdade de expressão, o que inclui: (a) liberdade de imprensa e outros meios de comunicação; (b) liberdade de receber ou transmitir informações ou ideias; (c) liberdade de criatividade artística; e (d) liberdade acadêmica e liberdade de pesquisa científica". ao Parlamento 18 meses para corrigir a violação à Constituição. Durante esse período, determinou que a seção 10, no que tange à conceituação questionada, deve ser lida da seguinte maneira: "10(1) Nenhuma pessoa pode defender o ódio baseado em raça, etnia, gênero, religião ou orientação sexual e que constitua incitação a causar danos". A decisão precisa ser confirmada perante a Corte Constitucional, cujo posicionamento está pendente ${ }^{44}$.

Subjacente à esta discussão está a publicação pelo jornalista Qwelane de um artigo intitulado "Me chame de qualquer coisa, mas GAY não". Isto causou grande indignação na comunidade LGBT+, que apresentou uma queixa na Comissão de Direitos Humanos da África do Sul (SAHRC) por discurso de ódio baseado na Seção 10 do Equality Act. A Comissão acionou a Equality Court e Qwelane fez um pedido à High Court, contestando a conformidade da seção $10 \mathrm{com}$ a Constituição. Em julgamento consolidado ${ }^{45}$, esses dois tribunais pontuaram que não é preciso prova de dano concreto no discurso de ódio, sendo suficiente a potencialidade de causá-lo. Assim, a declaração do jornalista equivaleria ao discurso de ódio como previsto na lei. Contudo, em 29 de novembro de 2019, o Supremo Tribunal de Apelação decidiu recurso interposto pelo jornalista e entendeu de modo diverso ${ }^{46}$, sustentando que por mais que se deva proteger a igualdade e a dignidade de todos, a lei teria promovido limitação injustificável da liberdade de expressão ao vedar discurso que não cause dano ou incite ódio. A decisão, como mencionado no item precedente, está pendente perante a Suprema Corte.

Há duas instituições no país responsáveis pela aplicação dessa lei. Em primeiro lugar, a Comissão Sul-Africana dos Direitos Humanos (SAHCR) é, geralmente, o primeiro órgão que os indivíduos procuram para uma queixa que se refere a uma violação de direitos humanos, o que pode resultar em ações judiciais posteriores com assistência jurídica prestada pela própria Comissão. Em segundo lugar, a Equality Court tem o propósito de julgar assuntos especificamente relacionados a violações do direito à igualdade, discriminação e discursos de ódio. ${ }^{44}$ Em junho de 2020, quando esse artigo foi finalizado, o processo
(CCT13/20) estava em fase de audiências. O andamento do caso
pode ser conferido em: < https://collections.concourt.org.za/han-
dle/20.500.12144/36639>. Acesso em: 02 jun. 2020 .
45 South African Human Rights Commission v. Qwelane (2017).
46 Qwelane v. South African Human Rights Commission and Another
(686/2018). Disponível em: <http://www.saflii.org/za/cases/
ZASCA/2019/167.html>. Acesso em: 02 jun. 2020. 
Em 2019, foi aprovado o Plano Nacional de Combate ao Racismo, Discriminação Racial, Xenofobia e Intolerância Relacionada (NAP), cuja finalidade é complementar a legislação, políticas e programas existentes que tratam da igualdade e discriminação. Dessa forma, tem como objetivos, dentre outros, estabelecer uma linha de estudo para determinar os níveis de discriminação, desenvolver um repositório virtual das estatísticas, realizar campanhas de conscientização que incentivem o público a denunciar os incidentes de intolerância, investigar causas e natureza das manifestações proferidas e promover educação antirracista e antidiscriminatória.

Buscando implementar o cenário de repressão ao discurso de ódio no país, o projeto da Lei de Prevenção de Crimes de Ódio e Discurso de Ódio, conhecida como Hate Speech Bill, foi liberada para comentário público no início de $2019^{47}$. O projeto criminaliza as manifestações de ódio, prevendo punição com multa e/ou prisão de até três anos a quem as proferir. O documento tem deflagrado grandes questionamentos e dividido a sociedade a respeito de sua necessidade. Diz-se que a criminalização deve ser interpretada de maneira que atinja um equilíbrio constitucionalmente adequado entre a liberdade de expressão e os interesses em promover a dignidade humana, e que a simples proibição do discurso de ódio em leis civis e penais não é suficiente para combatê-lo em um país historicamente divido pela discriminação racial ${ }^{48}$. Seria preciso, antes de tudo, continuar combatendo as raízes desses preconceitos por meio de políticas públicas de educação e conscientização social.

\subsubsection{Jurisprudência}

A jurisprudência na África do Sul conta com uma quantidade significativa de casos ligados a manifesta-

\footnotetext{
${ }^{47}$ No momento em que esse artigo foi finalizado, em junho de 2020, a lei ainda se encontrava em tramitação na Assembleia Nacional. O acompanhamento do processo legislativo está disponível em: <https://pmg.org.za/bill/779/>. Acesso em: 02 jun. 2020.

48 Para uma discussão sobre a adequação da lei e do tratamento que ela confere ao discurso de ódio no país, cf. ISAACK, Wendy. South African Move on Hate Speech a Step Too Far. Human Rights Watch, fev. 2017. Disponível em: <https://www.hrw.org/ news /2017/02/21/south-african-move-hate-speech-step-too-far $>$. Acesso em: 02 jun. 2020; VOS, Pierre De. Hate speech Bill could be used to silence free speech. Daily Maverick, fev. 2019. Disponível em: <https://www.dailymaverick.co.za/opinionista/2019-02-26hate-speech-bill-could-be-used-to-silence-free-speech/>. Acesso em: 02 jun. 2020.
}

ções de ódio e é composta por decisões da Corte Constitucional, das High Courts e da Equality Court. Em que pese a grande maioria desses julgados dizer respeito a questões raciais, alguns casos emblemáticos foram decididos em relação à orientação sexual, como visto acima no caso do jornalista Qwelane, e à liberdade religiosa. Como exemplo deste segundo caso, destacamos que a High Court (Johannesburg) já considerou ser discurso de ódio a publicação de caricaturas do profeta Mohammed que estereotipavam, humilhavam e tratavam o Islamismo de forma indigna ${ }^{49}$.

Quanto às decisões envolvendo questões raciais, há casos de discurso de ódio proferido contra judeus, chineses e indianos, como a decisão que reconheceu que afirmar que os judeus não morreram por causa das câmaras de gás na Segunda Guerra Mundial, mas, sim, por doenças infecciosas, em particular tifos, não incidiria em proibição legal ${ }^{50}$.

A maioria dos casos no país sobre raça, contudo, está ligada ao embate entre brancos e negros. Já se reconheceu a proibição de entoar uma antiga canção do Apartheid que falava em atirar no grupo étnico branco então no poder ${ }^{51}$; rechaçou-se o discurso que compa-

49 Em Jamiat-Ul-Ulama of Transvaal v. Johncom Media Investment Ltd and Others (2006), uma organização islâmica local entrou com uma petição para proibir diversos canais da mídia de publicar caricaturas do profeta Mohammed. A Corte deu razão ao requerente e proibiu a publicação, concluindo que o desenho ridicularizava o Islamismo de uma forma não só humilhante, mas também indigna. Assim, limitar a liberdade de expressão quando esta serve para disseminar o ódio e estereotipar uma minoria religiosa ajudaria a curar os sectarismos do passado e a fomentar a união nacional.

${ }^{50}$ Em 2001, a Islamic Unity Convention exibiu um programa em que um entrevistado questionou a legitimidade do Estado de Israel e o Sionismo como uma ideologia, afirmando que os judeus não morreram por causa das câmaras de gás na Segunda Guerra Mundial, mas, sim, por doenças infecciosas, em particular tifos. Perante a Corte, foi alegado que o programa violou a cláusula 2(a) do Código de Conduta para Serviços de Radiodifusão, que proibia que fossem veiculados materiais ofensivos aos sentimentos de qualquer setor da população ou suscetíveis de prejudicar relações. A Corte entendeu, em Islamic Unity Convention v Independent Broadcasting Authority and Others (2002), que a lei era ampla e vaga e que teria realizado uma restrição inconstitucional à liberdade de expressão, declarando que o discurso proferido estava protegido pela Constituição.

51 Em 2011, a Equality Court de Johannesburg, considerou, em AfriForum and Another v Malema and Others, que uma antiga canção do Apartheid constituía um discurso de ódio proibido de acordo com a Seção 10 do Equality Act. Na oportunidade, Julius Malema cantou "atire no Boer/fazendeiros, atire no Boer/fazendeiros eles são estupradores/ladrões (...) eles estão com medo, covardes, você deve atirar no Boer, eles roubam, esses cães". A letra se refere aos Afrikaners, o grupo étnico branco que governou o país durante a era do apartheid. A Corte entendeu que a canção poderia ser empregada 
rava pessoas negras a macacos e mostrava indignação pelo fato de negros poderem usar praias $^{52}$; e foi considerada discurso de ódio a manifestação de um proprietário que, sob justificativa de inferioridade dos negros, proibia esse grupo de frequentar sua pousada ${ }^{53}$.

Em 2018, a Equality Court de Guateng proferiu interessante decisão na qual considerou um funcionário do governo de Guateng, Velaphi Khumalo, culpado por discurso de ódio contra brancos, após sua declaração de que "os brancos na África do Sul merecem ser hackeados e mortos como judeus. Vocês têm o mesmo veneno. Olhe para a Palestina. Vocês devem queimar vivos e esfolados e sua prole usada como fertilizante de jardim". Em South African Human Rights Commission v. Khumalo, o Tribunal, reconhecendo o "infeliz e lamentável” legado de "tensões sociais significativas nas quais, entre outras distinções sociais, somos marcados e categorizados por raça e aparência pessoal", pontuou que a Constituição

para demonstrar uma intenção de machucar, incitar o mal e promover o ódio contra os Afrikaners, constituindo, portanto, um discurso de ódio vedado.

52 Em 2016, declarações racistas foram gravadas nas mídias sociais e discursos de natureza racial ocuparam o espaço sociopolítico do país. Penny Sparrow, uma mulher branca, comparou pessoas negras a macacos e expressou sua frustração com o fato de negros usarem a praia de Scottburgh. Na ocasião, Gareth Cliff, personalidade de rádio e televisão famosa no país, afirmou que as pessoas não entendiam a liberdade de expressão, sendo interpretado pelo público como apoiador dos comentários de Sparrow (PEOPLE DON'T UNDERSTAND freedom of speech: Gareth Cliff. Businesstech, 30 jan. 2016. Disponível em: <https://businesstech.co.za/news/ media/110791/people-dont-understand-freedom-of-speech-gareth-cliff/>. Acesso em: 03 nov. 2019). Nesse mesmo período, um conhecido economista e comentarista, Chris Hart, sugeriu, no Twitter, que as vítimas do apartheid começaram a ter um crescente senso de direito (STANDARD BANK'S CHRIS Hart resigns after racista Twitter row. News24, Cidade do Cabo, mar. 2016. Disponível em: $<$ https://www.news24.com/SouthAfrica/News/standard-bankschris-hart-resigns-after-racist-twitter-row-20160314>. Acesso em: 02 nov. 2019). O caso de Sparrow chegou à Court Equality, que entendeu, em ANC v Sparrow (2016), que Penny preferiu discurso de ódio contra negros, tendo sido condenada ao pagamento de uma multa.

53 Em 2018, Andre Slade, proprietário de uma pousada, e sua parceira eslovaco, Katarina Krizaniova, foram condenados pela High Court Of South Africa Kwazulu-Natal Local Division no caso Ismangaliso Wetland Park and Another v Sodwana Bay Guest Lodge and Another ao pagamento de uma multa em razão de discursos de ódio proferidos contra negros. O episódio ganhou destaque em 2016, quando Slade enviou um e-mail proibindo negros de frequentarem a sua pousada em Sodwana Bay. Indignação ainda maior foi gerada quando justificaram a proibição perante a mídia afirmando que "de acordo com a lei de Deus, temos que ter algum tipo de segregação entre a criação que ele deixou aqui (...) Os negros eram servos e a Bíblia deixou bem claro (...) Não temos o mesmo sangue, pele, cabelo e existem cerca de 300 diferenças (...) Negros não eram pessoas”. começou a transformar a sociedade repudiando a hostilidade interracial, "para que possamos construir uma nação com um consenso de que todo sul-africano merece dignidade e que toda a nossa comunidade, através do compartilhamento de recursos e do respeito mútuo, pode experimentar coesão social”. Por isso, é uma escolha política do país declarar intoleráveis "declarações que têm o efeito de incitar as pessoas a causar danos". Nesse sentido, a Corte pontuou:

A escolha de valor na Constituição é que devemos superar as fissuras entre nós. Isso não pode acontecer se, em debate, uma parte da população é licenciada para ser condenatória porque seus membros foram vítimas de opressão e a outra parte, entendida como, coletivamente, os ex-opressores são disciplinados a permanecer em silêncio. A realidade é que, dada a nossa história, os sul-africanos brancos coletivamente têm muito a responder. No entanto, explosões injuriosas contra os brancos, por esses motivos, não contribuem em nada para a coesão social. (...) Em resumo, a seção 10 deve ser entendida como um instrumento para promover a coesão social. A "diferença" de brancos ou qualquer outra identidade racial é inconsistente com nossos valores constitucionais. Essas declarações, na medida em que, com dramáticas alusões ao holocausto, estabelecem uma lógica para repudiar os brancos como indignos e que eles merecidamente devem ser perseguidos, marginalizados, repudiados e sujeitos à violência aos olhos de um leitor razoável poderia, de fato, ser interpretado para incitar a causar do dano por reações dos negros que endossam essas atitudes e reações dos brancos à desmoralização, respondendo da mesma maneira. Portanto, esses desenvolvimentos, em uma escala suficientemente grande, descarrilam a transformação da sociedade sul-africana.

Em sentido similar, na decisão Strydom v. Black First Land First, proferida em 2019, a Equality Court of Johannesburg entendeu que o slogan Terra ou Morte, escrito pelo partido Black First Land First por meio de seu líder Andile Mngxitama, constitui discurso de ódio contra brancos.

No mesmo ano, após uma petição da Fundação Nelson Mandela perante a Equality Court, foi decidido que a antiga bandeira da África do Sul introduzida a partir de 31 de maio de 1928 e usada em todo o apartheid até sua extinção, em 27 de abril de 1994, constituía discurso de ódio e discriminação injusta contra negros. Nesse sentido, qualquer exibição que não fosse uma expressão artística, acadêmica ou jornalística de interesse público deveria ser levada à Corte. $\mathrm{Na}$ decisão Nelson Mandela Foundation Trust and Another v. Afriforum NPC and Others (2019), foi considerado que: 
Em resumo, a Bandeira Velha foi adotada em junho de 1927 por um parlamento composto apenas por brancos e foi posta em operação em 1928. Por isso, às vezes é chamada de Bandeira de 1928 ou Bandeira Velha. Foi abolida em 1994 pelo primeiro parlamento democrático e não-racial da África do Sul que representa todo o povo do país. Tinha 66 anos durante os quais era um símbolo da África do Sul, representando os direitos das minorias sul-africanas brancas à exclusão dos sul-africanos negros. É, portanto, não surpreendentemente, visto de maneira diferente até hoje, principalmente por pessoas brancas, por um lado, e pessoas negras, por outro. Foi substituída em 1994 pela nova bandeira nacional, que representa uma África do Sul democrática não racial unida. (...) A Bandeira Velha ou a Bandeira do Apartheid (como às vezes também é chamada) era um símbolo vívido da supremacia branca e da privação e supressão de negros. (...) Expressou a herança europeia, excluindo inteiramente os negros do projeto de unir todas as partes do povo em um mesmo sentimento.

\subsubsection{Análise crítica}

Na África do Sul o modelo jurídico é o alternativo, uma vez que há, de um lado, proibições do discurso de ódio abstratas em lei, e, de outro, previsão de medidas alternativas para o combate dessas manifestações. Configura-se, assim, um tratamento misto do tema no país, com importantes contribuições regulatórias e jurisprudenciais. Adota-se um conceito amplo de discurso de ódio, uma vez que os tribunais entendem que manifestações de ódio podem ser feitas contra todas as pessoas, e não somente contra minorias políticas. Isso é explicado pela tendência de um discurso reconciliatório, isto é, há um estímulo para a construção de unidade nacional, voltada para a transformação da sociedade altamente afetada pela divisão racial histórica. Assim, vigora uma releitura do instituto do discurso de ódio, tradicionalmente direcionado à proteção de pessoas vulneráveis, passando a englobar qualquer pessoa, inclusive as que detém instrumentos de poder na sociedade. Nessa perspectiva, é interessante observar que ao adotar tal posicionamento a Corte sul-africana passou a admitir uma maior quantidade de hipóteses de discurso de ódio, restringindo de forma mais intensa a liberdade de expressão. De acordo com os julgados apresentados, para um discurso ser considerado odioso em razão da raça, a gravidade e intensidade das palavras não precisa ser demasiada, bastando que incentive de alguma maneira a violência, o cerceamento de direitos ou a subjugação. Esse entendimento, contudo, foi recentemente revisto pelo Supremo Tribunal de Apelação, e uma manifestação da Corte Constitucional está pendente para se definir uma conceituação ampla ou restrita de discurso de ódio.

\subsection{Argentina}

\subsubsection{Breve contextualização}

A Argentina é o país da América do Sul que recebeu mais imigrantes ao longo de sua história ${ }^{54}$. No entanto, sua identidade foi construída com base na subordinação dos grupos minoritários de origem não europeia, instalada a partir dos diversos obstáculos ao reconhecimento dos direitos e particularidades desses indivíduos, em especial dos povos indígenas e afrodescendentes. No continente, a Argentina é vista como o exemplo mais paradigmático de estímulo à imigração de trabalhadores europeus a fim de substituir os de descendência africana $^{55}$, e, sobretudo no século XIX, foi construída a narrativa que enaltecia o imigrante europeu e defendia intervenções sobre a raça e a cultura para se abandonar o caráter "bárbaro" e se alcançar um país civilizado e com progresso ${ }^{56}$.

A exclusão dos migrantes e outros povos persiste até hoje ${ }^{57}$, sendo inclusive estimulada por agentes go-

${ }^{54}$ Sobre os processos migratórios na América Latina, sobretudo na Argentina, cf. LANZA, André Luiz; LAMOUNIER, Maria Lucia. A América Latina como Destino dos Imigrantes: Brasil e Argentina (1870-1930). Cadernos Prolam/USP, v. 14, n. 26, p. 90-107, 2015; DEVOTO, Fernando. Historia de la Inmigración en Argentina. Buenos Aires: Sudamericana, 2002; PIZARRO, Jorge Martínez (Ed.). América Latina y el Caribe: migración internacional, derechos humanos y desarrollo. Santiago de Chile: CEPAL, 2008.

${ }_{55}$ HERNÁNDEZ, Tanya Katerí. Subordinação racial no Brasil e na América Latina: o papel do Estado, o Direito Costumeiro e a Nova Resposta dos Direitos Civis. Trad. de Arivaldo Santos de Souza e Luciana Carvalho Fonseca. Salvador: EDUFBA, 2017, p. 34 e ss.

${ }^{56}$ COURTIS, Corina et al. Racism and discourse: a portrait of the argentine situation. In: DIJK, Teun A. van (Ed.). Racism and Discourse in Latin America. New York: Lexington Books, 2009, p. 13-56.

${ }^{57}$ Nesse sentido, confira-se, por exemplo, GRIMSON, Alejandro; KESSLER, Gabriel. On Argentina and the Southern Cone: Neoliberlism and National Imaginations. New York; London: Routledge, 2005, p. 117-146; ANDERSON, Judith M. A million little ways: racism and everyday performances of blackness in Buenos 
vernamentais. De acordo com um relatório de 2017 apresentado pelo Gabinete do Alto Comissariado para os Direitos Humanos (OHCHR) sobre as formas contemporâneas de racismo, discriminação racial, xenofobia e outras intolerâncias na Argentina, menciona um episódio em que funcionários do governo fizeram declarações na mídia acusando os migrantes de serem responsáveis pelo narcotráfico no país e de participarem de atividades criminosas ${ }^{58}$.

\subsubsection{Modelo jurídico}

A Constituição da Argentina de 1853 protege a liberdade de expressão em seu artigo $14^{59} \mathrm{e}$, embora indique em seu artigo 16 que "todos os seus habitantes são iguais perante a lei” ${ }^{60}$, não menciona o princípio da não discriminação. Por outro lado, a Lei no 23.592 de 1988, que criminaliza atos discriminatórios, proíbe expressamente o discurso de ódio em seu artigo $3^{\circ}$, penalizando não apenas o incitamento ao ódio contra certos grupos vulneráveis, mas também a propagação de ideias baseadas na superioridade racial, étnica ou religiosa:

Art. $3^{\circ}$. Serão punidos com prisão de um mês a
três anos, quem participar de uma organização
ou realizar publicidade com base em ideias ou
teorias de superioridade de uma raça ou grupo
de pessoas de determinada religião, origem étnica
ou cor, cujo objeto é a justificação ou promoção
da discriminação racial ou religiosa sob qualquer
forma. Aqueles que de alguma forma encorajam ou
incitam perseguição ou ódio contra uma pessoa ou

Aires. African and Black Diaspora: An International Journal, v. 7, n. 2, p. 165-176, 2014.

58 UNITED NATIONS HUMAN RIGHTS OFFICE OF THE HIGH COMMISSIONER. Report of the Special Rapporteur on contemporary forms of racism, racial discrimination, xenophobia and related intolerance on his mission to Argentina, [S.l], abr. 2017. Disponível em: <https://ap.ohchr.org/documents/ dpage_e.aspx?si=A/HRC/35/41/Add.1>. Acesso em: 02 nov. 2019.

59 Constituição da Argentina de 1853, Artigo 14. "Todos os habitantes da Nação gozam dos seguintes direitos, de acordo com as leis que regulam seu exercício, a saber: trabalhar e exercer todos os setores legais; navegar e negociar; peticionar às autoridades; entrar, permanecer, transitar e sair do território argentino; publicar suas ideias pela imprensa sem censura prévia; usar e descartar sua propriedade; associar-se a propósitos úteis; professar livremente seu culto, de ensino e aprendizagem".

${ }^{60}$ Constituição da Argentina de 1853, Artigo 16. "A nação argentina não admite prerrogativas de sangue ou nascimento: não há privilégios pessoais ou títulos de nobreza. Todos os seus habitantes são iguais perante a lei e admissíveis nos empregos sem outra condição que não a adequação. A igualdade é a base dos impostos e encargos públicos". grupos de pessoas por causa de sua raça, religião, nacionalidade ou ideias políticas.

A mesma penalidade será aplicada a quem, de qualquer forma, incentivar ou iniciar perseguição ou ódio contra uma pessoa ou grupos de pessoas por causa de sua raça, religião, nacionalidade ou ideias políticas.

Já a Lei de Migração (Lei no 25.871/2004) garante paridade de acesso a direitos aos migrantes e suas famílias $\left(\operatorname{art.} 6^{\circ}\right)$ e prevê que, ainda que os migrantes sejam irregulares, não poderão ser impedidos de acessar a educação, seja em instituições públicas ou privadas. No artigo 13, proíbe atos discriminatórios de forma expressa:

Artigo 13: Para os fins desta lei, são considerados discriminatórios todos os atos ou omissões determinados por razões como etnia, religião, nacionalidade, ideologia, opinião política ou sindical, sexo, gênero, posição econômica ou características físicas, que arbitrariamente impeçam, obstruam, restrinjam ou de alguma forma prejudiquem o exercício pleno em bases iguais dos direitos e garantias fundamentais reconhecidos na Constituição Nacional, nos Tratados Internacionais e nas leis.

Por fim, a Lei Nacional de Educação (Lei $n^{\circ}$ 26.206/2006), em seu artigo 11, traz como um de seus objetivos "garantir condições de igualdade, respeitando as diferenças entre as pessoas sem admitir discriminação de gênero ou qualquer outra". Nesse sentido, no artigo 79, exige o desenvolvimento de políticas para a "promoção da igualdade educacional visando o enfrentamento de situações de injustiça, marginalização, estigmatização e outras formas de discriminação derivadas de fatores socioeconômicos, culturais, geográficos, étnicos, de gênero ou quaisquer outros".

Apesar da criminalização do discurso de ódio na Argentina, existem outros mecanismos não punitivos através dos quais se pretende proteger setores discriminados da população. Em 1995, por meio da Lei n ${ }^{\circ}$ 24.515, foi criado o Instituto Nacional contra a Discriminação, Xenofobia e Racismo (INADI), cujo objetivo é o desenvolvimento de políticas nacionais e de medidas concretas para combater manifestações de ódio. $\mathrm{O}$ INADI recebe denúncias sobre condutas discriminatórias e mantém um registro nacional, oferece um serviço de aconselhamento gratuito para pessoas ou grupos discriminados, projeta e promove campanhas de conscientização voltadas à valorização do pluralismo social e cultural, elabora planos de combate à discriminação, e oferece cursos gratuitos sobre discriminação e direitos. 
Nesta mesma linha, foram criados observatórios específicos. O Observatório de Discriminação em Rádio e Televisão tem a finalidade de analisar conteúdos para determinar se são discriminatórios. Se assim forem classificados, a análise feita poderá ser divulgada publicamente, com o intuito de aumentar a conscientização, e os responsáveis pela produção ou disseminação do material são convidados a participar de um diálogo, durante o qual são sugeridas apenas recomendações, não sendo aplicada nenhuma sanção ou multa. Além disso, uma das propostas centrais do Observatório é organizar workshops sobre questões relacionadas ao direito de não ser discriminado.

Da mesma forma, o Observatório de Discriminação no Futebol tem o objetivo de realizar ações específicas no esporte. Como essa é uma área importante para a vida social e cultural do país, o órgão se vale da visibilidade do esporte para enviar uma mensagem antidiscriminatória a um elevado número de pessoas. Suas ações incluem a análise de comportamentos, conteúdos e comentários que expressem qualquer discriminação, preconceito ou estigmatização. Assim, dentre outras medidas, organiza treinamentos para árbitros e jogadores, denuncia práticas ou discursos discriminatórios, promove valores de tolerância através de materiais de divulgação, realiza a assinatura de acordos de cooperação mútua entre clubes a fim de se atingir o respeito pela diversidade e inclusão no esporte, busca acessibilidade para todos e realiza recomendações aos jornalistas.

Igualmente, o Observatório da Web trabalha para construir uma internet livre de discriminação, sendo um canal simples para denunciar sites com conteúdo intolerante.

Em 2012, por meio da Lei no 26.522, foi criada a Defensoria Pública de Serviços de Comunicação Audiovisual, cujo objetivo é promover, disseminar e defender o direito à comunicação democrática em todo o território nacional. Dessa forma, atua recebendo reclamações e consultas, bem como aumentando a conscientização por meio de resoluções, cursos e audiências públicas.

Por fim, destaca-se também a Secretaria de Direitos Humanos e Pluralismo Cultural, que tem como um de seus objetivos a implementação efetiva de padrões nacionais e internacionais que garantam os direitos e liberdades fundamentais de grupos vulneráveis. Nesse sentido, possui um centro dedicado ao recebimento de reclamações e orientação aos cidadãos, de modo que organiza o entendimento entre as partes em conflito ou encaminha os casos ao sistema judicial, juntamente com uma opinião baseada nas evidências coletadas.

\subsubsection{Jurisprudência}

Embora a construção cultural da sociedade Argentina possa induzir ao pensamento de que manifestações de ódio e discriminação contra minorias são recorrentes no cenário do país, a jurisprudência da Corte Constitucional não segue essa intuição. Raros são os casos resolvidos pelo Judiciário que tratam de xenofobia e discriminação racial contra negros e indígenas. Uma explicação para esse fato pode ser atribuída a deficiências no acesso à justiça e à impermeabilidade dos tribunais às pautas relacionadas aos grupos marginalizados.

O já mencionado relatório apresentado pelo OHCHR aponta que o Ministério da Defesa Pública afirmou que em diversos casos envolvendo indígenas e migrantes, os tribunais "não haviam decidido, atrasaram as considerações dos casos ou não seguiram o devido

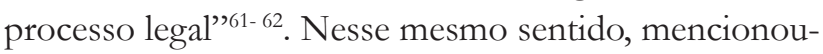
-se, com base em dados do Ministério da Justiça e Direitos Humanos, que entre 2004 e 2013, não houve sentenças ligadas a violações da Lei Antidiscriminação e "entre 2013 e 2016, 32 casos foram registrados com uma violação do artigo 2 da Lei Antidiscriminação. Destes 32 casos, 21 foram arquivados em tribunais de primeira instância e 11 encerrados. No mesmo período, 47 casos foram registrados pelo crime de promoção ou incitamento à perseguição ou ao ódio" por razões discriminatórias ${ }^{63}$.

Apesar disso, há importantes decisões de tribunais inferiores, como o caso de Mazzini Uriburu, que proferiu comentários racistas em um supermercado, afirmando para uma senhora negra e seu neto negro que "esses negros, têm que matar todos eles desde que eram pequenos" ${ }^{64}$. A instância criminal considerou que as pa-

${ }^{61}$ UNITED NATIONS HUMAN RIGHTS OFFICE OF THE HIGH COMMISSIONER. Op. cit., p. 15.

62 Importante observar que já foi reconhecido no país o direito de ser ouvido, isto é, o direito ao intérprete nas audiências de imigrantes. Cf. a decisão de 2010 do Tribunal Superior de Justicia de la Ciudad Autonoma de Buenos Aires: Bara, Sakho s/ queja por recurso de inconstitucionalidad denegado en Mbaye, Ibrahima (Habeas Corpus), expediente $n^{\circ}$ 6925/09.

63 UNITED NATIONS HUMAN RIGHTS OFFICE OF THE HIGH COMMISSIONER. Op. cit., p. 15.

${ }^{64}$ A decisão foi proferida em 21 de março de 2003 no Juzgado Na- 
lavras proferidas por Mazzini foram ditas em um local público e em um tom alto de voz, transcendendo o escopo de discussão entre duas pessoas. Dessa forma, foi condenado ao crime de incitar o ódio em razão da raça, juntamente com o crime de ameaça, ambos previstos na Lei no 23.592/88.

Grande parte dos casos jurisprudenciais de discurso de ódio diz respeito ao povo judeu. Uma explicação possível é o fato de a comunidade judaica estar bem integrada no país, mantendo boas interações com os diferentes órgãos governamentais e participando de ações para combater práticas discriminatórias e manifestações de antissemitismo na esfera pública. Dentre esses casos, podemos mencionar a negativa de reconhecimento jurídico a um partido político que imitava o partido nazista e previa a promoção do desprezo ou ódio racial, religioso ou nacional ${ }^{65}$; a condenação de pessoas que distribuíram panfletos em vias públicas e deram entrevista a um jornal afirmando que os judeus tinham como objetivo dominar a nação argentina e escravizar os cristãos argentinos ${ }^{66}$; a proibição de comercialização de um filme de propaganda nazista de 1940, sem atualização de interpretação ou conteúdo, por incentivar o ódio ${ }^{67}$; a

cional en lo Criminal y Correccional $\mathrm{N}^{\circ}$ 2. Mazzini Uriburu, $\mathrm{Fa}$ cundo s. infracción Ley 23.592, n 2639/00.

${ }_{65}$ Em 2009, a Corte Suprema de Justiça da Nação decidiu o caso do Partido Nuevo Triunfo (sentencia $\mathrm{n}^{\circ} 1469$ ), no qual negou-lhe reconhecimento de personalidade político-legal, uma vez que o partido, imitação do Partido Nacional Socialista dos Trabalhadores Alemães da década de 1930, incluía em seu programa político a promoção do desprezo ou ódio racial, religioso ou nacional. Adotando como base as ideias de que é um dever das nações atuar contra a repetição dos crimes contra a humanidade cometidos pelo nazismo e que o desestímulo e a neutralização do "desenvolvimento de práticas que incitam ao ódio racial ou religioso, e a subjugação e eliminação de pessoas" em virtude dessas características, a Corte decidiu "impedir o proselitismo em favor de uma oferta política", cujo programa se direciona a reproduzir ideias nazistas.

${ }^{66}$ A Câmara Nacional de Apelação Penal julgou, em 1999, o caso Ricardo José y otros (sentencia $\mathrm{n}^{\circ}$ 1856), em que os acusados incitaram o ódio e promoveram a perseguição de judeus por meio de documentação distribuída nas vias públicas, como panfletos, boletins e folhetos, e através de entrevista publicada pelo jornal NCO concedida ao diretor do ElDiario. Nessas manifestações, destacam-se passagens como a ideia de que "[a] diabólica sociedade judaica oculta" objetivaria "dominar nossa nação" e "o livro de cabeceira de judeus e maçons [seria destinado] para escravizar os cristãos (...) argentinos ... temos que agir!!!”. A Câmara confirmou a condenação proferida em primeira instância e esclareceu que, além da propaganda, a mera participação em um grupo dessa classe é reprimida.

67 A Câmara Nacional de Apelação Penal considerou, em 1999, ao julgar o caso Héctor y otra, que a comercialização de filmes como "O Eterno Judeu", baseado em ideias sobre a superioridade de uma raça e com mensagens depreciativas aos pertencentes à comunidade proibição de um blog que divulgava ideias antissemitas e destacava que "o judaísmo não é uma religião, mas uma comunidade racial antagônica à raça branca e à sua sobrevivência, e, como tal, é declarada guerra sem quartel" ${ }^{68}$; e a vedação do discurso que, após o atentado às torres gêmeas em 2001, comparou o islamismo ao nazismo e defendeu sua destruição ${ }^{69}$. Sem embargo desses precedentes, a Câmara Nacional de Apelação Criminal já considerou que afirmar que "os judeus não gostam de coisas difíceis" e por isso não se tornariam árbitros de futebol da primeira divisão, não configura

judaica, seria um meio de incentivar e promover o ódio em razão da raça. Na ocasião, entendeu-se que a venda "sem ter sido submetida a interpretações com a intenção de atualizar ou esclarecer seu conteúdo, é precisamente a renovação do objetivo para o qual foi criada, ou seja, incentivar o ódio a todos aqueles que pertencem à comunidade judaica”. Nesse ponto, é relevante esclarecer que o julgado em questão não trata especificamente do incentivo ao ódio pela fala, mas sim por qualquer outro meio, sendo aplicado, portanto o art. $3^{\circ}$, $\int 2^{\circ}$ da Lei ${ }^{\circ} 23.592$

${ }_{68}$ Em 2017, o caso do blog La Opinion Probibida (sentencia $\mathrm{n}^{\circ}$ 4356/17), que continha cerca de 300 publicações que incitavam o ódio contra a comunidade judaica, chamou a atenção, sendo julgado pelo Foro Penal do Poder Judiciário da Cidade de Buenos Aires. No início da página havia a descrição "Somente para antissemitas convencidos. Os 'contaminados' são avisados de que este blog não é para você ... para evitar traumas desnecessários, aconselho uma fuga honrosa", e mais a frente declarava que "O judaísmo não é uma religião, mas uma comunidade racial antagônica à raça branca e à sua sobrevivência, e, como tal, é declarada guerra sem quartel. O judaísmo e todas as suas manifestações são nossos inimigos!!!”. Ressalta-se que entre as publicações mais recentes, havia artigos intitulados "Os judeus e o sangue", "Análise muito sistemática da escória judaica", "Bastardos judeus" e "Nojo judaico". Dessa forma, considerou-se que em alguns casos extraordinários a liberdade de expressão deve ceder, como no analisado, pois "não há espaço para dúvidas sobre a ilegalidade das publicações mencionadas, e uma suposta restrição não pode ser invocada no processo de disseminação de ideias para manter as opiniões graves ativas, uma vez que não mostra como a opinião pública se beneficia do uso de expressões degradantes como aqueles que podem ser notados lendo o portal". 69 Esse é um dos casos mais emblemáticos no reconhecimento contra o discurso de ódio, tendo sido decidido em 2004 pela Câmara Nacional de Apelações Criminais. Trata-se do caso Cherashny (sentencia ${ }^{\circ}$ 882), que envolvia manifestações contra a religião islâmica. Um jornalista havia feito declarações islamofóbicas após o ataque contra as torres gêmeas em 2001, afirmando que "o problema é o Islã, é uma religião baseada na deificação da guerra, (...) onde eles querem matar (...), são uma merda nazista, (...) e você sabe o que eu penso? Que com os nazistas, como aconteceu na Segunda Guerra Mundial, não devemos negociar, devemos destruí-los". É interessante ressaltar que a Corte aplicou o padrão americano sobre o discurso de ódio ao considerar que as expressões usadas são suscetíveis de criar um clima hostil em que os destinatários do discurso podem ser incitados à violência. Dessa forma, o que justificaria a restrição do Estado à liberdade de expressão seria apenas a iminência do risco. Assim, considerando a publicidade, a intensidade da mensagem e a proximidade temporal para o ataque, foi decidido que de fato haveria o discurso de ódio. 
discurso de ódio, por mais que desrespeite a diferença de raças e $\operatorname{credos}^{70}$.

\subsubsection{Análise crítica}

$\mathrm{Na}$ Argentina, adota-se um modelo jurídico alternativo, pois, ao mesmo tempo em que o discurso de ódio é criminalizado, diversas medidas não penais foram criadas para combater a produção e a disseminação de conteúdo discriminatório e que incentive o ódio e a violência.

Tanto a lei quanto a jurisprudência exercem importante papel no país no combate ao discurso de ódio, traduzindo um tratamento misto. A jurisprudência se limita a decisões de tribunais inferiores, não tendo a Suprema Corte muitas decisões sobre o tema. Os julgados tratam, em sua maioria, de manifestações de ódio contra os judeus, o que não parece traduzir a realidade das declarações de ódio no país, evidenciando problemas estruturais no combate à discriminação.

Por fim, o país traz um conceito restrito de discurso de ódio, uma vez que os casos dos últimos anos mostram que a jurisprudência, apesar de mais flexível, se aproxima do modelo americano ${ }^{71}$, exigindo um nexo de causalidade específico entre a manifestação e a criação de um clima propenso à discriminação e à violência.

\footnotetext{
70 A Câmara Nacional de Apelação Penal julgou, em 2004, o caso Julio $H$. (sentencia $n^{\circ}$ 79), reconhecendo que a manifestação do presidente da Associação de Futebol Argentino, Julio Grondona, no sentido de que "os judeus não se tornam árbitros da primeira divisão do futebol argentino, porque o mundo do futebol é difícil, trabalhoso. Os judeus não gostam de coisas difíceis" não teve o condão de incitar o ódio, apesar de ser incompatível com o respeito entre as diferentes raças e credos.

${ }^{71}$ Como afirma Eduardo Bertoni, antigo Relator Especial para a liberdade de expressão na Comissão Interamericana de Direitos Humanos: "O princípio fundamental da jurisprudência dos EUA é que o Estado não pode restringir uma expressão com base em seu conteúdo. (...) uma determinada ideia não pode ser restringida pelo fato de ser prejudicial, perigosa ou ofensiva. (...) a Suprema Corte dos EUA afirmou que o discurso dessa natureza será protegido pela Primeira Emenda da Constituição, a menos que a exortação pública seja direcionada a incitar ou produzir uma ação ilegal iminente" BERTONI, Eduardo. Estudio sobre la prohibición de la incitación al odio en las Américas. OHCHR, [s.d.], p. 15. Disponível em: <https://www.ohchr.org/Documents/Issues/Expression/ICCPR/Santiago/SantiagoStudy_sp.pdf>. Acesso em: 20 dez. 2019. Sobre o tratamento norte-americano do discurso de ódio, cf., ainda, WALDRON, Jeremy. Op. cit.; e HERZ, Michael; MOLNAR, Peter. The Content and Context of Hate Speech: Rethinking Regulation and Responses. Cambridge: Cambridge University Press, 2012.
}

\subsection{Colômbia}

\subsubsection{Breve contextualização}

A Colômbia é marcada por desigualdades multidimensionais. Afrocolombianos e indígenas sofrem diversas formas de discriminação étnico-racial, como violência, deslocamento e baixa representação política ${ }^{72}$, e são também os grupos mais pobres, que mais enfrentam problemas de saúde e de acesso à educação ${ }^{73}$. A subordinação de minorias políticas é um traço do passado e do presente na Colômbia. A história do país "começa com a escravidão e graves violações dos direitos dos afrodescendentes" ${ }^{\text {"74 }}$, que construíam suas comunidades em locais isolados e enfrentavam a pobreza. O legado da escravidão ainda mostra suas consequências, sobretudo nos grupos social e economicamente marginalizados ${ }^{75}$.

Atualmente, o país é um dos mais desiguais da América Latina, apresentando o coeficiente de desigualdade de Gini de $0,497^{76}$, segundo pesquisa realizada pelo Departamento Administrativo Nacional de Estatística (DANE) em 201877. Os dados socioeconômicos e as informações estatísticas oficiais não representam com precisão a realidade do país, uma vez que não consideram variadas categorias étnicas, dificultando a tomada de medidas adequadas para o combate à discriminação ${ }^{78}$. Desse modo, políticas públicas para o enfrenta-

72 Ibidem, passim. Cf., também, RODRÍGUEZ-GARAVITO, C.; SIERRA, T. A.; ADARVE, I. C. (Coords.). Racial Discrimination and Human Rights in Colombia: A Report on the Situation of the Rights of Afro-Colombians. Bogotá: Universidad de Los Andes, Facultad de Derecho, CIJUS, Ediciones Uniandes, 2008.

73 CASTILLO, S. S.; ABRIL, N. G. P. Discourse and racism in Colombia: five centuries of invisibility and exclusion. In: DIJK, Teun A. van (Ed.). Racism and Discourse in Latin America. New York: Lexington Books, 2009, p. 131-170.

${ }^{74}$ HUMAN RIGHTS COUNCIL. Report of the independent expert on minority issues, Gay McDougall: Mission to Colombia. [S.I], jan. 2011, p. 3.

75 Ibidem, p. 5.

76 O Coeficiente de Gini é um indicador de desigualdade que mede a concentração de riqueza em uma determinada área geográfica, assumindo valores entre zero e um, onde zero representa igualdade absoluta e um, desigualdade absoluta. Em 2018, na América Latina, o país com valor mais baixo era o Uruguai, com 0,391 . O de valor mais alto era o Brasil, com 0,540. Cf. COMISIÓN ECONÓMICA PARA AMÉRICA LATINA Y EL CARIBE. Panorama Social de América Latina. Santiago: Naciones Unidas, 2019, p. 42.

77 Sobre a situação de pobreza e desigualdade econômica no país, cf. DANE - Información para todos. Boletín técnico de pobreza monetária na Colômbia 2018. Bogotá, maio 2019.

${ }^{78}$ V. HUMAN RIGHTS COUNCIL. Op. cit., 2011. 
mento do cenário de desigualdade não ganham papel de destaque na agenda política da Colômbia, e a violência e a discriminação continuam a ser preocupações constantes ${ }^{79}$. Diante disso, como será visto, a efetividade das leis existentes no país é desafiada pela ausência de políticas públicas complementares que viabilizem combater com sucesso os casos de discurso de ódio, bem como pela falta de instituições especializadas destinadas ao atendimento às vítimas e de programas para conscientização e formação de uma cultura antidiscriminatória.

\subsubsection{Modelo jurídico}

A Constituição Política da Colômbia de 1991 protege a liberdade de expressão no artigo 20, limitando-se a dizer que os meios de comunicação de massa devem atuar com responsabilidade social ${ }^{80}$, e também consagra a igualdade e a proteção contra a discriminação no artigo $13^{81}$. O texto constitucional não apenas proíbe a discriminação, como estabelece um mandamento para promoção da igualdade, devendo o Estado adotar medidas em favor de grupos marginalizados.

No plano infraconstitucional, a partir da reforma promovida pela Lei Antidiscriminação (Lei $\mathrm{n}^{\circ}$ 1.482/2011), o Código Penal passou a punir atos de

\footnotetext{
79 NACIONES UNIDAS. Informe del Alto Comisionado de las Naciones Unidas para los Derechos Humanos sobre la situación de Derechos Humanos en Colombia durante el año 2018 (A/HRC/40/3/Add.3). 2019. Disponível em: < https:// www.hchr.org.co/index.php/informes-y-documentos/informesanuales/9017-informe-del-alto-comisionado-de-las-naciones-unidas-para-los-derechos-humanos-sobre-la-situacion-de-derechoshumanos-en-colombia-durante-el-ano-2018>. Acesso em: 20 jan. 2020 .

${ }^{80}$ Constituição Política da Colômbia de 1991, Artigo 20. "É garantida a toda pessoa a liberdade de se expressar e divulgar seus pensamentos e opiniões, para informar e receber informações verdadeiras e imparciais, e a dos meios de comunicação de massa.

Estes são gratuitos e têm responsabilidade social. $\mathrm{O}$ direito à retificação é garantido em condições justas. Não haverá censura".

${ }^{81}$ Constituição Política da Colômbia de 1991, Art. 13. "Todas as pessoas nascem livres e iguais perante a lei, receberão a mesma proteção e tratamento das autoridades e gozarão dos mesmos direitos, liberdades e oportunidades sem discriminação baseada no sexo, raça, origem nacional ou familiar, língua, religião, opinião política ou filosófica.

O Estado promoverá as condições para que a igualdade seja real e eficaz e adotará medidas em favor de grupos discriminados ou marginalizados.

O Estado protegerá especialmente as pessoas que, devido à sua condição econômica e física, ou mental, estão em uma circunstância de fraqueza manifesta e sancionará abusos ou maus-tratos cometidos contra eles".
}

intolerância e incitação ao ódio. Em relação ao crime de racismo ou discriminação, é prevista punição no artigo 134A para "qualquer pessoa que impeça, obstrua ou restrinja arbitrariamente o exercício pleno dos direitos das pessoas por causa de sua raça, nacionalidade, sexo ou orientação sexual, incapacidade e outras razões de discriminação". Nessa mesma linha, o artigo 134B pune quem incita a violência ${ }^{82}$.

A norma foi contestada três vezes perante a Corte Constitucional Colombiana. No primeiro caso, argumentou-se que a lei deveria ser declarada inconstitucional, pois o procedimento legislativo teria ignorado diretrizes estabelecidas e o seu conteúdo seria incompatível com princípios constitucionais ${ }^{83}$. A Corte, entretanto, decidiu pela inépcia da demanda, que não cumprira os requisitos de certeza, pertinência e suficiência (Sentencia C-282, de 2013).

No segundo caso, questionou-se a ausência de consulta prévia aos grupos étnicos para formação da norma. Contudo, a Corte sustentou que as normas eram disposições gerais sobre discriminação, que não afeta-

${ }^{82}$ Código Penal Argentino, Art. 134B. "Promove ou instiga atos, comportamentos que constituem assédio, orientado a causar danos físicos ou morais a uma pessoa, grupo de pessoas, comunidade ou pessoas, por causa de sua raça, etnia, religião, nacionalidade, ideologia política ou filosófica, sexo ou orientação sexual ou incapacidade e outros motivos de discriminação".

${ }^{83}$ A argumentação foi no sentido de que "Primeiro, levando em conta que a lei acrescentou um novo fator de discriminação proibido, não previsto no catálogo taxativo previsto no artigo 13 da Constituição, e que, com isso, a Carta Política foi modificada, deveriam ser observadas as regras para a aprovação de atos legislativos, e não de leis comuns, como foi feito.(...) Segundo, mesmo ignorando a consideração anterior e assumindo que a categoria de "orientação sexual" é comparável à de "sexo" contida no artigo 13 da Constituição, em qualquer caso, os regulamentos devem ter sido processados de acordo com as regras das leis estatutárias e não das leis ordinárias, uma vez que seu objetivo é "garantir a proteção dos direitos de uma pessoa, grupo de pessoas, comunidade ou pessoas que são violadas por atos de racismo ou discriminação.(...) Terceiro, na medida em que o projeto de lei foi contestado pelo Presidente da República por razões de inconstitucionalidade, era necessária uma maioria qualificada por sua insistência e encaminhamento ao Tribunal Constitucional. (...) Finalmente, dado que a lei visa garantir direitos ameaçados ou violados por atos de racismo ou discriminação, o projeto deveria ter sido consultado com minorias nas quais a lei tem impacto. (...) Quanto aos vícios materiais, o peticionário afirma que, em nome da diversidade sexual, o direito do réu anula o princípio da igualdade, bem como as liberdades de consciência, cultos e expressão, consagrados nos artigos 18, 19 e 20 do texto constitucional A razão para isto é que a regra impede, através da penalização, a manifestação e expressão da oposição e a rejeição da maioria das confissões religiosas em relação a tendências sexuais alternativas, como homossexualidade, zoofilia e necrofilia". 
vam direta e especificamente essas comunidades, mas interessavam a todos os indivíduos, razão pela qual não haveria necessidade de consulta prévia (Sentencia C-194, de 2013).

Por fim, no terceiro caso, alegou-se que a lei seria parcialmente omissa, pois não incluía a condição de incapacidade como critério de discriminação passível de punição penal. A Corte entendeu que não há obrigação de proteger as pessoas com deficiência através da adoção de sanções penais, pois a discriminação sofrida por elas seria diferente da sofrida por outros grupos ${ }^{84}$ (Sentencia C-671, de 2014). Tal aspecto foi altamente criticado em audiência pública por convidados que eram a favor da declaração de inconstitucionalidade e consideravam que as situações, condições e características dos grupos eram similares.

No que tange à utilização de métodos alternativos, a

84 A Corte destacou as seguintes distinções: “(i) em primeiro lugar em relação à origem desse problema, enquanto os preceitos criminalizaram a discriminação de origem pessoal, a restrição dos direitos desse grupo decorre principalmente da origem institucional; (ii) em segundo lugar, no que diz respeito ao padrão de discriminação, enquanto a lei sanciona o que tem um componente de ódio, hostilidade e animosidade, a afetação dos direitos em questão se origina em um tipo de discriminação que falta esse ingrediente e, em vez disso, é especificado em sentimentos de piedade, indiferença e desconforto; (iii) em terceiro lugar, no que se refere à maneira pela qual a discriminação se materializa, enquanto os controversos preceitos criminalizam discursos e atos inequívocos de ataque e exclusão, no caso de pessoas com deficiência, isso está incorporado em valores imaginários, atitudes e maneiras não verbalizadas; (iv) Quarto, com relação à notoriedade do fenômeno, enquanto a Lei 1482 de 2011 sanciona as formas mais visíveis e notórias desse problema, esse grupo populacional enfrenta manifestações mais sutis, imperceptíveis e invisíveis (a chamada "discriminação invisível "); (v) em quinto lugar, no que diz respeito à intencionalidade, enquanto a lei proíbe ataques que sejam executados, de forma clara e inequívoca, devido a critérios de discriminação suspeitos ou proibidos, como raça, etnia, origem nacional , sexo, orientação sexual, religião ou afiliação política ou religiosa, geralmente em relação as pessoas com deficiência os atos discriminatórios carecem desse componente intencional ou cuja intencionalidade é ambígua ou difusa; além disso, enquanto as discriminações protegidas pela lei contemplam apenas a chamada "discriminação direta", na qual ocorre exclusão ou marginalização devido a esses critérios, geralmente a população com deficiência está sujeita a "discriminação indireta", na qual o acesso a bens e oportunidades sociais estão sujeitos a fatores neutros e imparciais, mas como não levam em consideração a desvantagem desses grupos no jogo social, acabam excluindo-os e marginalizando-os desse acesso; (vi) finalmente, enquanto à luz dos artigos 3 e 4 da Lei 1482 de 2011, raça, etnia, nacionalidade, sexo, orientação sexual, religião e filiação política ou filosófica constituem critérios necessários e suficientes para a criação de um ato discriminatório, muitas vezes a restrição ou limitação dos direitos desse grupo está associada à sua confluência com outros fatores de discriminação e condições que colocam objetivamente as pessoas em desvantagem, como a situação socioeconômica".
Colômbia não apresenta nenhum mecanismo acessório relevante no combate ao discurso de ódio, o que acaba por afetar o cumprimento da legislação existente, como será visto adiante.

\subsubsection{Jurisprudência}

Poucas são as decisões proferidas pelo poder judiciário ligadas ao discurso de ódio e à não discriminação, o que demonstra uma ineficácia da mera criminalização das condutas. Há apenas uma decisão adotada com base na Lei Antidiscriminação. Na ocasião, Fernando Antonio Delgado, então vereador de um município colombiano, foi condenado por declarar publicamente que "sendo honesto, grupos difíceis de gerenciar, como negros, deslocados e indígenas, são um câncer que os governos nacional e mundial têm". Delgado foi condenado em primeira instância, ocasião em que o fato de o discurso de ódio ter sido cometido por um funcionário público, através da mídia e ofendendo a dignidade de grupos minoritários, foi mais relevante para a penalização do que o incitamento a ações discriminatórias. Entretanto, a sentença foi revista e o vereador foi absolvido na instância superior ${ }^{85}$.

Há algumas decisões mais antigas da Corte Constitucional Colombiana nas quais se enfrentou a dicotomia entre liberdade de expressão e proteção da dignidade e igualdade das pessoas discriminadas. No entanto, o discurso de ódio não foi analisado diretamente. Em todos os casos houve uma constante: a exigência de que o exercício da liberdade de expressão fosse enquadrado em um propósito constitucionalmente legítimo. Logo, quando o discurso incentiva a violência, se torna ilegítimo, isto é, não protegido pela liberdade de expressão ${ }^{86}$. Em 2004, por exemplo, o tribunal defendeu que "o princípio da finalidade como requisito para o exercício da liberdade de expressão está relacionado com a realização de um propósito constitucionalmente legítimo", e que "a liberdade de expressão não pode se tornar uma ferramenta para violar os direitos dos outros ou para

\footnotetext{
85 Trata-se da decisão proferida pela Sala Penal de Decisión del Tribunal Superior de Pereira em 26 de abril de 2016 (Hostigamiento por raza n 12-4662, Rel. Manuel Yarzagaray Bandera).

${ }^{86}$ Existe uma ampla controvérsia sobre as formas de interpretar a liberdade de expressão, havendo quem decomponha seu alcance com base na finalidade e quem realize a ponderação com base no princípio da proporcionalidade. Sobre o tema, v. PEREIRA, Jane Reis Gonçalves. Interpretação Constitucional e Direitos Fundamentais. 2. ed. São Paulo: Saraiva, 2018.
} 
encorajar a violência" (Sentencia T-787/04).

Já na Sentencia T-391, de 2007, a Corte definiu que a liberdade de expressão não é protegida nos seguintes casos:

(a) propaganda a favor da guerra; (b) incitação ao ódio nacional, racial, religioso ou outro que constitua incitação à discriminação, hostilidade, violência contra qualquer pessoa ou grupo de pessoas por qualquer motivo (modo de expressão que abrange as categorias comumente conhecidas como discurso de ódio, discurso discriminatório, incitação ao crime e violência); (c) pornografia infantil; e (d) incitação direta e pública a cometer genocídio.

Em 2010, um caso emblemático de discriminação ocorreu dentro de uma universidade contra um estudante afrocolombiano. $\mathrm{Na}$ ocasião, um professor falou enquanto encarava o único aluno negro da turma: "um valor de 1 seria como um manobrista que deve atender 25 carros em 25 minutos, o que indicaria que ele sempre ficaria ocupado... o que seria um tráfico de escravos, eles o fariam trabalhar como negro! (...) como um escravo cujo mestre deve chicoteá-lo para trabalhar... trabalhar!'. Diante dessa manifestação, a Corte Constitucional concluiu na Sentencia T-691, de 2012:

Para a Sala, (i) quando usado em sala de aula, por um professor, expressão que mantém e preserva estereótipos racistas e escravos em estruturas linguísticas, é promovido um tratamento exclusivo, que marginaliza as pessoas consideradas parte de um certa 'raça'. Promover, justificar ou preservar o uso de expressões racistas no campo da educação, bem como tornar invisível seu conteúdo discriminatório, ignora os direitos à igualdade e à não discriminação, ao mesmo tempo em que assume tratamento cruel e degradante. Portanto (ii) uma pessoa, como professora, viola os direitos à educação e à igualdade (especialmente o direito a não ser discriminado), quando usa uma expressão claramente racista durante uma aula para apresentar um exemplo, em especialmente se pudesse ser facilmente substituído por outro. Promover, justificar ou preservar o uso de expressões racistas no campo da educação, bem como invisibilizar seu conteúdo discriminatório, ignora os direitos à igualdade e à não-discriminação, ao mesmo tempo em que impõe tratamento cruel e degradante.

$\mathrm{Na}$ ocasião, a Corte não fez referência em qualquer momento a discurso de ódio. No entanto, o Centro de Estudos Dejusticia e o Observatório de Discriminação Racial da Universidade de Los Andes, na qualidade de terceiros, indicaram que houve incitação à subordinação dos afrodescendentes:

Dado o elemento de ódio ou preconceito social, a pantomima que acompanha o discurso mostra um elemento burlesco que denota tratamento desrespeitoso com a população afrodescendente. A ênfase na ideia de tratamento do negro como escravo, longe de ter uma nuance crítica diante do passado de escravidão sofrido por essa população, revela uma intenção de colocar afrodescendentes no lugar de subordinados. O elemento de violência está presente na forma de expressão do professor: a zombaria constante, os gestos que ele fez com as mãos e a inferência que ele faz quando ressalta que é motivo de riso que um de seus alunos possa se refletir em tal situação de escravidão.

\subsubsection{Análise crítica}

A Colômbia adota um modelo predominantemente repressivo, não trazendo medidas alternativas, como políticas públicas, para lidar com o discurso de ódio. $\mathrm{O}$ cenário colombiano demonstra que a simples criação de penalidades para manifestações discriminatórias e de ódio pode ser inadequado e ineficiente e, mesmo com essa previsão, ser baixo o número de casos solucionados pelo Poder Judiciário ou levados ao conhecimento dos setores responsáveis.

Trata-se de um cenário de tratamento misto, com predomínio da regulação punitiva. Mesmo com a promulgação da Lei Antidiscriminação, apenas uma decisão foi proferida tendo a norma como base. Nesse caso em específico, o discurso questionado foi relacionado à discriminação em relação à raça. Isso pode ser explicado pelo próprio aspecto cultural subjacente, em que a escravidão foi um instrumento de consolidação da marginalização por séculos.

\section{4 Î́ndia}

\subsubsection{Breve contextualização}

Apesar da grande diversidade religiosa da Índia, o discurso de ódio em razão de religião é uma constante no país. Aspectos históricos de intenso conflito entre hindus e muçulmanos ajudam a explicar essa realidade, evidenciando uma sociedade extremamente dividida e intolerante ${ }^{87}$. Com isso, os casos de violência contra 
minorias religiosas constituem um problema histórico, tendo suas raízes na desarmonia comunal entre os dois grupos mencionados e também na divisão da Índia na época da independência, em 1947. O fim do Império Britânico resultou na divisão em dois países independentes, a Índia e o Paquistão, cuja partilha baseou-se primordialmente em questões religiosas. Houve uma migração em massa de 15 milhões de pessoas (muçulmanos para o Paquistão e hindus e sikhs para Índia), acompanhada por violentas revoltas, milhares de vítimas e milhões de refugiados.

Atualmente, comunidades minoritárias, especialmente muçulmanos, cristãos e sikhs, têm sofrido numerosos incidentes de intimidação e violência por grupos nacionalistas hindus. Os casos de crimes de ódio com base religiosa aumentaram desde que o governo nacionalista pró-hindu do Partido Bharatiya Janata (BJP) chegou ao poder em 2014. De acordo com relatório do Human Righs Watch ${ }^{88}$, entre maio de 2015 e dezembro de 2018, pelo menos 44 pessoas, 36 delas muçulmanas, foram mortas em 12 estados indianos. Nesse mesmo período, cerca de 280 pessoas ficaram feridas em mais de 100 incidentes diferentes ocorridos em 20 estados. Ainda de acordo com o documento, os ataques foram liderados pelos chamados grupos de proteção às vacas, hindus militantes que frequentemente têm vínculos com o BJP.

As manifestações de ódio se apresentam muitas vezes em relação à proibição da carne bovina, pois os hindus consideram que as vacas são animais sagrados. Assim, grupos de "vigilantes de vacas" patrulham as estradas, matando os suspeitos de outras religiões que contrabandeiam esse tipo de carne.

Considerando tal cenário, diferentes conflitos religiosos tiveram destaque nos últimos anos, como Banduria (2017), Kaliachak (2016), Muzaffarnagar (2013) e Gujarat (2002) ${ }^{89}$. Alguns desses conflitos são originários de discursos de ódio proferidos na internet, como o ataque em Banduria, West Bengal, em julho de 2017, que começou após um post ofensivo de um adolescente no Facebook $^{90}$.

${ }_{88}$ HUMAN RIGHTS WATCH. Violent Cow Protection in India: Vigilante Groups Attack Minorities. [S.l]: Human Rights Watch, 2019 , p. 6.

89 Sobre os conflitos recentes no país, cf. EMBREE, Ainslie T. Utopias in conflit: religion and nationalism in modern India. Berkley: University of California Press, 2018.

${ }^{9}$ DANIYAL, Shoaib. In-depth: How a Facebook post broke the

\subsubsection{Modelo jurídico}

A Constituição da Índia de 1949 protege a liberdade de expressão no artigo 19 e permite que o Estado crie leis com restrições razoáveis ao exercício deste direito em prol de alguns valores, como para evitar difamação ou incitação a uma ofensa ${ }^{91}$. Embora o discurso de ódio não encontre menção expressa, o direito à não discriminação é assegurado no artigo $15^{92}$.

A lista com valores que justificam restrições à liberdade de expressão prevista no artigo 19(2) é taxativa e a Suprema Corte da Índia já se manifestou indicando que a restrição deve ser razoável, o que significa dizer que "a limitação imposta a uma pessoa em gozo do direito não deve ser arbitrária ou de natureza excessiva" (Chintaman Rao v. The State of Madhya Pradesh, de 1950). Nessa mesma linha, afirmou em State of Madras v. V.G. Row (1952) que "é importante, neste contexto, ter em mente que o teste de razoabilidade, sempre que prescrito, deve ser aplicado a cada estatuto individual impugnado e nenhum padrão abstrato ou padrão geral de razoabilidade pode ser estabelecido como aplicável a todos os casos". Dessa forma, deve-se levar em consideração "a natureza do direito que supostamente foi violado, o objetivo subjacente das restrições impostas, a extensão e a urgência do mal a ser sanado, a desproporção da imposição e as condições prevalecentes na época".

O Código Penal Indiano, por sua vez, contém dis-

decades-long communal peace of a West Bengal town. Scroll.in, jul. 2017. Disponível em: <https://scroll.in/article/843692/in-depthhow-a-facebook-post-broke-the-decades-long-communal-peace-ofa-west-bengal-town>. Acesso em: 03 nov. 2019.

91 Constituição da Índia de 1949, artigo 19. “(1) Todos os cidadãos têm direito a: (a) liberdade de expressão; (...) (2) Nada na subcláusula (a) da cláusula (1) afetará o funcionamento de qualquer lei existente ou impedirá o Estado de fazer qualquer lei, na medida em que imponha restrições razoáveis ao exercício do direito conferido pela referida subcláusula no interesse da soberania e integridade da Índia, da segurança do Estado, das relações amistosas com Estados estrangeiros, da ordem pública, da decência ou moralidade ou em relação ao desrespeito à corte, difamação ou incitação a uma ofensa".

92 Constituição da Índia de 1949, artigo 15.“(1) O Estado não deve discriminar nenhum cidadão com base apenas em religião, raça, casta, sexo, local de nascimento ou qualquer um deles. (2) Nenhum cidadão deve, apenas com base na religião, raça, casta, sexo, local de nascimento ou qualquer um deles, estará sujeita a qualquer deficiência, responsabilidade, restrição ou condição em relação a: a) acesso a lojas, restaurantes públicos, hotéis e locais de entretenimento público; ou (b) o uso de poços, tanques, estradas e locais de recurso público mantidos total ou parcialmente fora dos fundos do Estado ou dedicados ao uso do público em geral". 
posições que restringem a liberdade de expressão. Entre elas, destaca-se a Seção $153 \mathrm{~A}^{93}$, que criminaliza a promoção da inimizade e atos prejudiciais à harmonia entre diferentes grupos de pessoas com base em religião, raça, local de nascimento, residência, idioma, entre outros. No caso do crime cometido em um local de culto ou cerimônias religiosas, a punição é mais severa, podendo ser de prisão de até cinco anos. Esse dispositivo foi analisado pela Suprema Corte da Índia no caso Gopal Vinayak Godse v. Union of India (1969), que forneceu padrões para avaliar o cometimento do crime:

(1) Não é necessário provar que a inimizade ou o ódio foram de fato causados entre as diferentes classes. (2) A intenção de promover inimizade ou ódio, além do que aparece na própria escrita, não é um ingrediente necessário da ofensa. Basta mostrar que a linguagem da escrita é de natureza calculada para promover sentimentos de inimizade ou ódio, pois presume-se que uma pessoa pretenda as consequências naturais de seu ato. (3) $\mathrm{O}$ assunto acusado de estar de acordo com a Seção 153A deve ser lido como um todo. Não se pode confiar em passagens isoladas e dispersas para provar a acusação, nem de fato pode tomar uma sentença aqui e outra ali e conectá-las por um processo meticuloso de raciocínio inferencial. (4) Para julgar

\footnotetext{
93 Código Penal Indiano, Seção 153A. "Promover inimizade entre diferentes grupos com base em religião, raça, local de nascimento, residência, idioma etc. ou age de forma prejudicial à manutenção da harmonia. (1) Quem (a) por palavras, faladas ou escritas, por sinais ou por representações visíveis ou de outra forma, promove ou tenta promover, por motivos de religião, raça, local de nascimento, residência, idioma, casta ou comunidade ou qualquer outro motivo, desarmonia ou sentimentos de inimizade, ódio ou má vontade entre grupos religiosos, raciais, de idioma ou regionais diferentes ou castas ou comunidades, ou (b) cometer qualquer ato que seja prejudicial à manutenção harmonia entre diferentes religiões, raças, idiomas ou grupos regionais ou castas ou comunidades e que perturbe ou é provável que perturbe a tranquilidade pública, (c) organize qualquer exercício, movimento, exercício ou outro atividade semelhante que pretenda que os participantes em tal atividade usem ou sejam treinados para usar força ou violência criminal, ou sabendo que é provável que os participantes em tal atividade usem ou sejam treinados para usar força ou violência criminal, ou participe de tal atividade que pretenda usar ou ser treinado para usar força ou violência criminal ou saber que é provável que os participantes em tal atividade usem ou sejam treinados para usar força ou violência criminal, contra qualquer grupo religioso, racial, de linguagem ou regional ou casta ou comunidade e tal atividade, por qualquer motivo que cause ou possa causar medo ou alarme ou um sentimento de insegurança entre os membros desse grupo religioso, racial, de idioma ou de região, casta ou comunidade regional, será punida com prisão que pode se estender por três anos, ou com multa, ou com ambos. (2) Ofensa cometida no lugar de culto, etc. Quem comete uma ofensa especificada na subseção (1) em qualquer local de culto ou em qualquer assembleia envolvida na realização de culto religioso ou cerimônias religiosas, deve ser punida com prisão que pode se estender por cinco anos e também pode ser multada".
}

quais são as consequências naturais ou prováveis da escrita, é permitido levar em consideração a classe de leitores para quem o livro se destina como também o estado de sentimentos entre as diferentes classes ou comunidades. (5) Se a redação é calculada para promover sentimentos de inimizade ou ódio, não há defesa de uma acusação nos termos da Seção 153A de que a redação contenha um relato verdadeiro de eventos passados ou seja de outra forma apoiada por uma boa autoridade. Se um escritor é desleal à história, pode ser mais fácil provar que a história foi distorcida para alcançar um fim específico, como por exemplo promover sentimentos de inimizade ou ódio entre diferentes classes ou comunidades. Mas a adesão ao caminho estrito da história não é, por si só, uma defesa completa de uma acusação sob a Seção 153A.

A Seção 153B do Código Penal ${ }^{94}$ pune afirmações prejudiciais à manutenção da harmonia comunal e da integridade nacional, isto é, atos propagados contra membros de determinado grupo com base na raça, casta, religião, entre outros, que possam gerar divisão na sociedade. Já a Seção $295^{95}$ criminaliza a destruição de locais de culto com a intenção de insultar a religião de uma classe de pessoas. Da mesma forma, a Seção $295 \mathrm{~A}^{96}$ criminaliza atos deliberados e maliciosos com a 94 Código Penal Indiano, Seção 153B. "Imputações, afirmações
prejudiciais à integração. (1) Quem, por palavras faladas ou escritas
ou por sinais ou por representações visíveis ou não: (a) faça ou pub-
lique qualquer imputação de que qualquer classe de pessoas não pos-
sa, por ser membro de qualquer grupo religioso, racial, de idioma ou
regional ou casta ou comunidade, suportar verdadeira fé e lealdade
à Constituição da Índia, conforme a lei estabelecida ou defender a
soberania e a integridade da Índia, ou (b) afirma, aconselha, propaga
ou publica que qualquer classe de pessoas por serem membros de
qualquer grupo religioso, raça, idioma ou região ou casta regional ou
comunidade seja negada ou privada de seus direitos como cidadãos
da Índia ou (c) faz ou publica afirmação, conselho, fundamento ou
apelação referente à obrigação de qualquer classe de pessoas, por
serem membros de qualquer grupo religioso, racial, de idioma ou
regional ou casta ou comunidade regional, e tal afirmação, causa ou
tem a capacidade de causar desarmonia ou sentimentos de inimizade
ou ódio ou má vontade entre esses membros e outras pessoas".
95 Código Penal Indiano, Seção 295. "Ferir ou profanar o local de
culto, com a intenção de insultar a religião de qualquer classe. Quem
destrói, danifica ou contamina qualquer local de culto ou qualquer
objeto mantido sagrado por qualquer classe de pessoas com a in-
tenção de insultar a religião de qualquer classe de pessoas ou com
o conhecimento de que qualquer classe de pessoas provavelmente
considerará tal destruição, dano ou contaminação como um insulto
à sua religião, será punido com prisão por um período que pode se
estender a dois anos, ou com multa, ou com ambos".
96 Código Penal Indiano, Seção 295 A. "Atos deliberados e malici-
osos destinados a ultrajar sentimentos religiosos de qualquer classe,
insultando sua religião ou crenças religiosas. - Quem quer que seja,
com intenção deliberada e maliciosa de ultrajar os sentimentos re-
ligiosos de qualquer classe de cidadãos da India, por palavras, fala-
das ou escritas, ou por sinais ou representações visíveis ou de outra 
intenção de ultrajar sentimentos religiosos de qualquer classe, insultando sua religião ou crenças religiosas, podendo este ocorrer por meio de palavras, sinais, representações visíveis ou outros.

O Código de Processo Penal também traz previsões sobre o tema ao reconhecer ao Estado, nas Seções 95 e 96, o poder de confiscar as publicações puníveis de acordo com o Código Penal Indiano.

Há outras leis no país que impactam diretamente na ideia de discurso de ódio, como a Scheduled Castes and Scheduled Tribes (Prevention of Atrocities) Act, de 1989, que protege da humilhação pública intencional os Scheduled Castes and Scheduled Tribes, grupos oficialmente designados na Constituição como pessoas historicamente desfavorecidas. Dessa forma, sob a Seção 3(1)(r), comete crime punido com prisão de 6 meses a 5 anos quem "ofende ou intimida intencionalmente com a intenção de humilhar um membro de uma Scheduled Caste ou de uma Scheduled Tribe, em qualquer lugar à vista do público".

A Lei de Proteção dos Direitos Civis de 1955 contém disposições que penalizam o discurso de ódio contra as comunidades dalit ou intocáveis. A Seção 7(1)(c) pune quem "por palavras, faladas ou escritas, ou por sinais ou por representações visíveis de outro modo, incita ou encoraja qualquer pessoa ou classe de pessoas ou o público em geral a praticar 'intocabilidade' de qualquer forma".

O discurso de ódio eleitoral também é regulado na Índia sob a Representation of the People Act (RoPA), de 1951. Em sua Seção 123(3A), considera uma prática corrupta "a promoção ou tentativa de promover sentimentos de inimizade ou ódio entre diferentes classes de cidadãos da Índia por motivos de religião, raça, casta, comunidade ou idioma, por um candidato a fim de melhorar as suas perspectivas de eleição ou afetar prejudicialmente a eleição de qualquer candidato". O candidato que praticar tal conduta perderá temporariamente o direito de ser votado, isto é, terá seus direitos políticos passivos suspensos. Justificando as razões para a existência da referida norma, a Suprema Corte se manifestou no caso Ziyauddin Bukhari v. Brijmohan Mehra (1975) dizendo que a Seção 123(2), (3) e (3A) foi promulgada com o intuito de "eliminar, do processo eleitoral, apelos aos fato-

forma, insultos ou tentativas de insultar a religião ou as crenças religiosas dessa classe, serão punidas com prisão de qualquer uma das descrições por um termo que pode se estender até três anos, ou com multa, ou com ambas". res divisivos que despertam paixões irracionais que são contrárias aos princípios básicos de nossa Constituição e, de fato, de qualquer civilização e ordem política e social". Nesse sentido, o “devido respeito às crenças e práticas religiosas, raça, credo, cultura e idioma de outros cidadãos é um dos postulados básicos de nosso sistema democrático". Logo, com base no "pretexto de proteger sua própria religião, cultura ou credo, uma pessoa não pode embarcar em ataques pessoais aos de outros, nem instigar animosidades ou medos irracionais entre grupos para garantir vitórias eleitorais".

A exibição de filmes na Índia também é alvo de regulação especial por meio do The Cinematograph Act, de 1952, e pelo Conselho Central de Certificação de Filmes (CBFC). De acordo com a Seção 5B da lei, o Conselho tem o poder de não certificar um filme, mesmo antes de sua exibição, quando ele "ou qualquer parte dele for contrário aos interesses da [soberania e integridade da Índia,] a segurança do Estado, relações amistosas com Estados estrangeiros, ordem pública, decência ou moralidade, ou envolva difamação ou desrespeito à corte ou tiver probabilidade de incitar o cometimento de qualquer ofensa".

A Suprema Corte já foi instada a se manifestar sobre a constitucionalidade dessa lei e, em $K A$ Abbas v. Union of India (1970), entendeu que o regime de censura era uma restrição razoável para equilibrar interesses individuais com interesses sociais e, assim, preservar a ordem pública. Ao argumento de que essa restrição não existiria em outras formas de expressão, a Corte pontuou que filmes podem despertar emoções mais profundas do que qualquer outra forma de arte, como livros e discursos.

Ademais, a Lei das Tecnologias de Informação de 2000 criminaliza o discurso de ódio online, tipificando quem envie, por meio de recurso informático ou dispositivo de comunicação informação que "seja grosseiramente ofensiva ou que tenha caráter ameaçador", ou que o emissor "saiba ser falsa, mas [envie] com o objetivo de causar aborrecimento, inconveniência, perigo, obstrução, insulto, lesão, intimidação criminal, inimizade, ódio ou má vontade, persistentemente, fazendo uso de dispositivo de comunicação" ou, ainda, quem envie "correio eletrônico ou mensagem de correio eletrônico com o objetivo de causar aborrecimentos ou inconvenientes ou enganar o destinatário sobre a origem dessas mensagens". A pena é de prisão de até 3 anos e multa. 
Em 2015, no entanto, no caso Shreya Singhal v. Union of India, a Suprema Corte da Índia invalidou o dispositivo por considerar que a proibição de disseminar informações destinadas a causar aborrecimentos, inconveniência ou insultos por meio de um recurso informático não se enquadrava em nenhuma exceção razoável ao exercício do direito à liberdade de expressão, não havendo nexo entre a discussão em si e o incitamento à violência.

\subsubsection{Jurisprudência}

A história de violência sectária na Índia traz consigo muitos casos judiciais envolvendo manifestações de ódio. Optamos, no presente estudo, por selecionar as decisões mais recentes e mais relevantes para o tema.

A jurisprudência do país engloba casos em que manifesta tendência à proteção da liberdade de expressão, interpretando as possibilidades de restrição desse direito de forma estrita. Assim, foi considerado possível veicular filme sobre o divórcio de um casal de hindus e muçulmanos, apesar da alegação de que ele promoveria desarmonia ${ }^{97}$; declarou-se invalidade de notificação governamental que permitia a recolha de um livro que tratava o rei Hindu Shivaji de forma depreciativa ${ }^{98}$; permitiu-se a circulação de um livro mesmo com a alegação de grupo religioso oposto no sentido de que a

${ }^{97}$ Em F.A. Picture International v. Central Board of Film Certification (2004), decidido pela Bombay High Court, questionava-se a recusa em certificar um filme que mostrava as dificuldades de um casal que se separou durante os conflitos entre hindus e muçulmanos. A CBFC recusou a certificação do filme pois entendeu que a "violência comunitária forçará a desarmonia; personagens e incidentes que são claramente identificáveis com personalidades reais, podendo levar à desarmonia; a violência em Gujarat é uma questão viva e uma cicatriz na sensibilidade nacional, cuja exibição pode agravar". O Supremo Tribunal de Bombaim, no entanto, considerou que a recusa violava a liberdade de expressão, sustentando que não necessariamente a narração da história promoveria violência, inimizade ou ódio.

98 Em State of Maharashtra v. Sangharaj Damodar Rupawate (2010), a Suprema Corte invalidou uma notificação do Governo de Maharashtra que ordenava o recolhimento de todas as cópias do livro Shivaji - Rei Hindu na Índia Islâmica. A notificação indicava que, na opinião do Governo, a circulação do referido livro, contendo referências escandalosas e depreciativas a Shivaji, causou inimizade entre várias comunidades e levou a atos de violência e desarmonia. $\mathrm{Na}$ oportunidade, a Corte considerou que "o poder de recolher um jornal, livro ou documento é um poder drástico”, pois afeta tanto a liberdade de expressão quanto o direito à privacidade, já que um policial tem ampla liberdade para procurar suspeitos em diversos lugares. Assim, "a disposição deve ser interpretada estritamente e o exercício do poder sob ela deve ser da maneira e de acordo com o procedimento adequado". obra ofenderia a religião por descrever um dos festivais que realiza como sexualmente promíscuo ${ }^{99}$.

Além disso, em 2014, no caso Pravasi Bhalai Sangathan $v$. Union of India, após uma petição requerendo que a Corte fornecesse instruções para a Comissão Eleitoral sobre discursos de ódio, entendeu-se que a questão merecia uma análise mais profunda pela Comissão de Direito da Índia. Ao decidir neste sentido, a Suprema Corte se manifestou sobre o que via como objetivo do discurso de ódio, destacando:

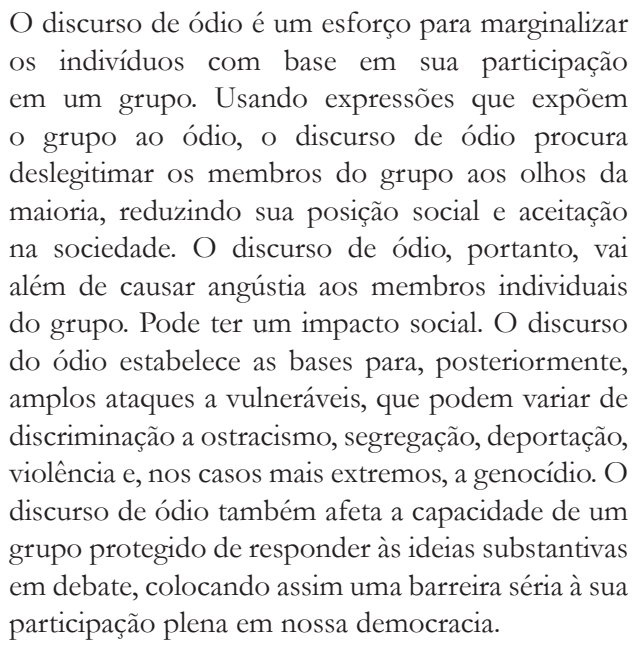

Diante disso, em março de 2017, a Comissão de Direito apresentou o Relatório $\mathrm{n}^{\circ} 267$ sobre discurso de ódio perante o governo da Índia. Por meio deste documento, sugeriu emendas ao Código Penal para acrescentar novas disposições sobre a "Proibição do incitamento ao ódio" na Seção 153B e Seção 505A. Também propôs outras estratégias para incentivar a harmonia na sociedade, como a adoção de medidas para sensibilização do público sobre o exercício responsável da fala.

\subsubsection{Análise crítica}

O modelo jurídico indiano é altamente repressivo. Apesar do elevado número de leis sobre discurso de ódio, não foram encontradas políticas públicas ligadas à prática, mas apenas a sua punição abstrata. A ampla criminalização não tem sido eficaz para coibir a intole-

\footnotetext{
99 No caso Murugan v. Tamil Nadu (2016), um grupo religioso se sentiu ofendido por passagens do livro Mathorubagan, que descrevia um festival como sexualmente promíscuo. O Comitê de Paz local ordenou que o autor emitisse um pedido de desculpas e foram apresentadas petições buscando uma ação criminal contra ele. O Supremo Tribunal de Madras, no entanto, descartou as alegações contra o livro e confirmou a liberdade de expressão do autor, ressaltando que esta não pode ser sacrificada para ceder às demandas da multidão.
} 
rância ${ }^{100}$, de modo que Anandita Yadav ${ }^{101}$ sugere alguns métodos alternativos de solução de controvérsia, como mediação vítima-agressor, programas de prevenção ao crime e de assistência às vítimas, e também o contradiscurso (counterspeech), isto é, a possibilidade de responder o conteúdo odioso de forma positiva, opções que estimulam o diálogo construtivo sem interferir na liberdade de expressão dos indivíduos.

O tratamento no país é misto, pois tanto as leis quanto a jurisprudência exercem importante papel na delimitação do entendimento do discurso de ódio. É interessante notar que os casos apresentados, em sua maioria, tratam de opiniões negativas sobre determinados momentos históricos e religiões, o que em outros países seria considerado como simples exercício da liberdade de expressão na vertente da liberdade religiosa. O discurso proselitista é da essência do exercício desta liberdade, sendo natural que a finalidade de influenciar o outro seja acompanhada de comparações ou expressões de animosidade ${ }^{102}$. Para Rodrigo Fuziger, "na prática, cada indivíduo crê que está professando sua fé dentro da religião correta e que aquela é a melhor para ele, sendo que esse movimento de certeza de sua crença já contém uma intrínseca hierarquização" 103 .

100 SALDANHA, Alison. 2017: A year of hate crimes in India: Number of violent incidents related to cows, religion is rising. Firstpost, 28 de dez. de 2017. Disponível em: <https://www.firstpost.com/ india/2017-a-year-of-hate-crimes-in-india-number-of-violent-incidents-related-to-cows-religion-is-rising-4278751.html>https:/ / www.firstpost.com/india/2017-a-year-of-hate-crimesin-india-number-of-violent-incidents-related-to-cows-religion-is-rising-4278751. html. Acesso em: 06 de set. de 2019.

101 YADAV, Anandita. Countering Hate Speech In India: Looking For Answers Beyond The Law. ILI Law Review, Nova Delhi, v. II, n. 6, Winter Issue 2018.

102 Sobre o tema, cf. BRASIL. Supremo Tribunal Federal. Recurso Ordinário em Habeas Corpus n 134682/BA. Rel. Min. Edson Fachin. Primeira Turma. Julg. 29 nov. 2016, DJE 29 ago. 2017.

103 FUZIGER, Rodrigo. Margeando o Estige: o direito penal e a limitação dos crimes de ódio relacionados à religião. Revista General de Derecho Penal, Madri, v. 19, p. 1-22, 2013. Em sentido similar, TAVARES, André Ramos. O direito fundamental ao discurso religioso: divulgação da fé, proselitismo e evangelização. Revista Brasileira de Estudos Constitucionais, Belo Horizonte, v. 3, n. 10, p. 17-47, abr./jun. 2009: "Uma teoria de primeira ordem carreia em seu bojo a concepção de que é a única e adequada, sendo as demais inválidas ou equivocadas; esta rejeição é, invariavelmente, intrínseca, quer dizer, acaba assumindo uma conotação religiosa; em outras palavras, não é apenas um afastar-se de outras religiões, mas sim um enxergar nelas conotações contra- religiosas. (...) Portanto, é pacífico o entendimento segundo o qual o proselitismo religioso, mesmo com os elementos que indubitavelmente o marcam, quais sejam, a negação e a desconsideração das demais religiões, gerando, em certo grau, uma animosidade é, em realidade, compreensível,
Deve-se considerar, no entanto, que a Índia vive intensas tensões e polarizações quando se trata de religião devido ao histórico conflito sectário. Um entendimento negativo a respeito de determinada religião considerado aceitável em um país ocidental pode ser visto como uma ofensa extremamente grave na Índia. Tal percepção varia de acordo com cada povo, cultura e história, e aqui, tem como consequência uma abrangência maior das hipóteses abstratas de discurso de ódio.

Assim, como visto, a legislação sobre o tema no país é de amplas restrições à liberdade de expressão. Em contrapartida, a jurisprudência desenvolveu uma tendência à proteção desta liberdade, demostrando sensibilidade mais elevada às representações da história de violência religiosa no país e derrubando muitas tentativas de suprimi-la. Com isso, seria possível afirmar, em tese, que estas posições favorecem um equilíbrio entre os direitos em colisão ${ }^{104}$. Ainda assim, manifestações de ódio continuam a ocorrer com frequência no país e a ampla criminalização, além de se tornar cada dia uma ameaça maior às liberdades comunicativas - na medida em que confere amplos poderes ao Estado para recolher livros e à CBFC na certificação de filmes -, não é efetiva no combate à disseminação de ódio.

\subsection{México}

\subsubsection{Breve contextualização}

Os dados discriminatórios do país revelam uma significativa marginalização do grupo LGBT+. De acordo com a Pesquisa Nacional Sobre Discriminação (ENADIS) de 2017, 20\% do total da população do México declarou ter sido discriminada no ano de 2016; 40\% da população homossexual declarou que teve direitos negados nos últimos cinco anos em razão de sua orientação sexual. Dentre as minorias, os migrantes e o grupo LGBT+ parecem sofrer uma maior discriminação direta, tendo em vista que a pesquisa indica que 39\% de homens e mulheres no país não alugariam um quarto

como elemento integrante da liberdade religiosa (tecnicamente, está alocado em seu núcleo essencial). (...) é natural do discurso religioso praticado pelas Igrejas, em especial pelas instituições daquelas religiões de pretensão universalista, pregar o rechaço às demais religiões. Esta postura integra o núcleo central da própria liberdade de religião".

104 Sobre o tema, cf. a decisão da Suprema Corte da Índia no caso Ramesh v. Union of India (1988). 
em sua casa para estrangeiros; $41 \%$ de homens e 33\% de mulheres não alugariam para pessoas transexuais; e $35 \%$ de homens e $30 \%$ de mulheres não alugariam para pessoas homossexuais. Ademais, $46 \%$ de homens e $40 \%$ de mulheres não concordariam com seu filho se casando com uma pessoa do mesmo sexo ${ }^{105}$.

Além disso, é importante ressaltar que as gerações de afrodescendentes e povos indígenas fizeram parte da construção da sociedade mexicana e foram alvos constantes de violência e discriminação ${ }^{106}$. Atualmente, esses grupos estão dispersos por todo território, mas a maioria vive em áreas rurais onde os serviços de educação e saúde são insuficientes, sofrendo com um alto grau de marginalização e atraso social. Nessa perspectiva, o Comitê para Eliminação de Discriminação Racial das Nações Unidas observou em relatório produzido em setembro de 2019 que "a discriminação racial estrutural e histórica contra os povos indígenas e a população mexicana de ascendência africana continua profundamente enraizada e é um obstáculo à construção de uma sociedade multicultural baseada na igualdade e na justiça" ${ }^{107}$. De fato, existem variadas razões para esse cenário, mas o baixo acesso à justiça dos grupos minoritários, a impunidade dos ofensores e o descaso e a banalização da violência pelo poder público são constantemente percebidos na sociedade mexicana ${ }^{108}$.

\subsubsection{Modelo jurídico}

A Constituição Política dos Estados Unidos Mexicanos de 1917 prevê a proibição de discriminação no item 5 de seu artigo $1^{\text {o109 }}$ e a liberdade de expressão no artigo

105 INEGI. Encuesta Nacional sobre Discriminación (ENADIS), [S.I]: INEGI, 2017.

106 Sobre o tema, cf. GUERREROS, A. C.; IZQUIERDO, J. G.; PINEDA, F. Racist discourse in Mexico. In: DIJK, Teun A. van (Ed.). Racism and Discourse in Latin America. New York: Lexington Books, 2009, p. 217-258; DIJK, Teun A. van. Racism and discourse in Spain an Latin America. Amsterdam/Philadelphia: John BenjaminsPublishing Company, 2005, p. 99-110.

107 COMMITTEE ON THE ELIMINATION OF RACIAL DISCRIMINATION (CERD). Concluding observations on the combined eighteenth to twenty-first periodic reports of Mexico, [S.1], 19 de set. de 2019, p. 3.

108 Ibidem, p. 3- 6.

109 Constituição Política dos Estados Unidos Mexicanos de 1917, Art. $1^{\circ}$. "É proibida qualquer discriminação baseada na origem étnica ou nacional, sexo, idade, deficiência, condição social, condições de saúde, religião, opiniões, preferências sexuais, estado civil ou qualquer outra que viole a dignidade humana e vise anular ou prejudicar os direitos e liberdades dos indivíduos". $6^{\circ}$, dispositivo que também prevê as limitações ao direito:

Art. $6^{\circ}$. A manifestação das ideias não será objeto de inquisição judicial ou administrativa, exceto no caso de um ataque à moral, à privacidade ou ao dano de terceiros, provocar qualquer ofensa ou perturbar a ordem pública; o direito de resposta será garantido nos termos da lei. O direito à informação será garantido pelo Estado.

Todos têm o direito de livre acesso a informações plurais e oportunas, bem como de buscar, receber e disseminar informações e ideias de todos os tipos, por qualquer meio de expressão.

O Estado garantirá o direito de acesso às tecnologias de informação e comunicação, bem como aos serviços de transmissão e telecomunicações, incluindo banda larga e internet. Para tais fins, o Estado estabelecerá condições de concorrência efetiva na prestação desses serviços.

Em 2003, foi promulgada a Lei Federal para Prevenir e Eliminar a Discriminação, com o intuito de regulamentar o art. 1(5) da Constituição. Destacamos o artigo $9^{\circ}$ da lei, que afirma que se deve interpretar discriminação como a promoção do ódio e da violência através dos meios de comunicação, bem como o incitamento ao ódio, violência, rejeição, zombaria, insulto, perseguição ou exclusão. Além disso, essa lei deu origem ao Conselho Nacional de Prevenção à Discriminação (CONAPRED).

O Código Penal Federal, por sua vez, tipifica o crime de discriminação, mas não criminaliza o discurso de ódio de forma expressa:

Artigo 149. Uma penalidade de um a três anos de prisão ou cento e cinquenta a trezentos dias de trabalho será aplicada em favor da comunidade e até duzentos dias de multa a que, por razões de origem ou associação étnica ou nacional, raça, cor da pele, idioma, sexo, sexo, preferência sexual, idade, estado civil, origem nacional ou social, status econômico ou social, condição de saúde, gravidez, opiniões políticas ou qualquer outro tipo que ameace a dignidade humana ou anule ou prejudique os direitos e liberdades das pessoas, realizando um dos seguintes comportamentos: I. Negar a uma pessoa um serviço ou benefício a que tem direito; II Negar ou restringir os direitos trabalhistas, principalmente por causa de gênero ou gravidez; ou limitar um serviço de saúde, principalmente às mulheres em relação à gravidez; III Negar ou restringir direitos educacionais.

No plano estadual, todos os 32 estados mexicanos possuem leis antidiscriminatórias; em 29 entidades federativas há a tipificação criminal de condutas relacionadas à discriminação nos códigos penais estatais ou outra legislação penal acessória; e em 27 constituições 
locais existem cláusulas antidiscriminatórias.

No país, há uma preocupação significativa com o combate à discriminação dos povos indígenas, de modo que além da extensa legislação dedicada exclusivamente à sua proteção, $\mathrm{o}$ artigo $2^{\circ} \mathrm{da}$ Constituição estabelece o dever para os estados de promoção da igualdade de oportunidades e eliminação de práticas discriminatórias. Nesse viés, algumas políticas públicas têm sido concebidas com a finalidade de diminuir as desigualdades existentes, como a criação do Instituto Nacional dos Povos Indígenas em 2018 e o Programa Nacional dos Povos Indígenas 2018-2024.

Em relação às políticas públicas adotadas em favor das minorias em geral, o Governo da República através do CONAPRED teve a iniciativa de criar algumas ações importantes, como as Salas de Paz, que reúnem organizações da sociedade civil, funcionários públicos, influenciadores, entre outros, com o objetivo de construir uma contranarrativa para discursos discriminatórios por meio de comentários sobre um tópico específico nas redes sociais, de modo a demonstrar que discursos de ódio podem ser substituídos por mensagens de paz; a criação do programa de educação a distância Conéctate, entre dezembro de 2012 e dezembro de 2017, em que foram ministrados programas educacionais sobre o direito à igualdade e à não discriminação; a criação de uma plataforma especializada em informações sobre discriminação que fornece estatísticas e estudos acerca da matéria; e a elaboração do Programa Nacional de Igualdade e Não Discriminação (PRONADI), que estabelece linhas de ação para cada instituição pública do Executivo Federal, a fim de revisar, incorporar e adaptar seus regulamentos e práticas para incorporar progressivamente a cultura antidiscriminatória e realizar ações para garantir direitos em condição de igualdade e não discriminação.

Todavia, apesar dos esforços do CONAPRED e de outras medidas alternativas adotadas por alguns estados da federação, como o Programa para Prevenir e Eliminar a Discriminação na Cidade do México (PAPED), a discriminação persiste com estatísticas altamente elevadas.

\subsubsection{Jurisprudência}

A jurisprudência mexicana sobre discurso de ódio é escassa. Muitos dos casos que tratam de liberdade de expressão estão ligados a questões clássicas, como a proibição de censura prévia, restrições indiretas e conflitos com o direito à honra. A única decisão mais próxima do objeto deste estudo envolve danos decorrentes da utilização de linguagem homofóbica, ou seja, uma manifestação que contribui para a manutenção do cenário discriminatório contra minorias, mas não trata, necessariamente, de discurso de ódio, que sequer foi mencionado pela Corte.

O caso, decidido em $2013^{110}$, surge de um processo de responsabilidade civil entre diretores de dois meios de comunicação em Puebla pelo suposto dano moral que um deles teria causado ao outro por conta de declarações feitas em uma coluna de jornal. O réu teria criticado o autor em uma coluna dizendo que este estava tentando "proteger sua imagem pública suja com meios falhos como colunas antigas, livros pagos, escritores pagos e colunistas bichas (...) tudo o que um colunista não deveria ser: bajulador, inútil e bicha (puñal)". A Suprema Corte de Justiça da Nação do México decidiu que esses insultos homofóbicos não são legalmente protegidos na constituição do país como liberdade de expressão, sustentando que, por mais que sejam expressões profundamente arraigadas na sociedade mexicana, as práticas da maioria da sociedade não podem validar violações à carta constitucional.

\subsubsection{Análise crítica}

Como se viu, os dados indicam alto grau de discriminação na sociedade mexicana, mas a Corte Constitucional não costuma analisar casos ligados a discursos de ódio. O tratamento do tema no país, assim, é predominantemente regulatório e alternativo, pois focado em políticas públicas. A única decisão apresentada, ligada a discursos homofóbicos, coopera para enfraquecer a ideia de proteção da liberdade de expressão em qualquer circunstância. É importante notar, no entanto, que no caso não houve instigação ao ódio, o que justifica a não referência a discurso de ódio.

Francisca Pou Giménez, professora de direito constitucional no Instituto Tecnológico Autônomo do México, reconhece a relevância da decisão para o debate sobre liberdade de expressão e não discriminação, mas

110 Trata-se do ADR - Amparo Direto em Revisión 2806/2012, decidido em 2013 pela Primera Sala de la Suprema Corte de Justicia de la Nación. 
pondera que um dos critérios utilizados pela Corte pode ter efeito excessivamente restritivo à manifestação de pensamento ${ }^{111}$. A Corte deu ênfase a duas regras principais para definir quando uma expressão constitui um ataque não protegido, a saber, quando a) é ofensiva e vexatória e b) não é relevante, isto é, não é necessária e pertinente para expressar as ideias do indivíduo. Nessa perspectiva, Giménez sustenta que avaliar uma declaração seguindo o critério da pertinência pode conduzir a reconstruções arbitrárias do objetivo ou valor do discurso.

De fato, essa possibilidade, que pode configurar censura com base em critérios subjetivos, deveria ter sido analisada pela Corte. No entanto, não se pode deixar de observar a importância da decisão no que tange à proteção das minorias discriminadas. Em um país como o México, com acesso altamente desigual à justiça, os litígios que chegam aos tribunais acabam por deixar muitas questões intocadas. O caso incorpora ideias substantivas pouco exploradas e particularmente relevantes no contexto sociocultural do país, além de oferecer uma oportunidade para que a análise do uso da liberdade de expressão seja aprofundada.

\section{Desafios e caminhos possíveis do tratamento do discurso de ódio no sul global}

É comum que os trabalhos de direito comparado adotem a metodologia funcionalista com o objetivo de encontrar a melhor solução sob o ângulo normativo para o problema em análise. Essa abordagem, contudo, parte da questionável premissa de que todos os países apresentam as mesmas dificuldades. É inegável que há questões similares enfrentadas por diferentes estados, mas é preciso levar em consideração aspectos contextuais que exigem enfoques específicos de acordo com a conjuntura. Foi possível verificar a aplicação desse argumento a partir dos países analisados neste estudo, pois, como se constatou, ainda que alguns apresentem a mesma base classificatória, têm aspectos únicos e diferenciadores no tratamento do discurso de ódio - o

111 POU GIMÉNEZ, Francisca. Libertad de expresión y discurso homofóbico en México: ¿Es correcta la teoría constitucional de la Suprema Corte? Boletín Mexicano de Derecho Comparado, v. 47, n. 140, p. 585-616, maio/ago. 2014. que atinge desde facetas basilares da questão, como sua conceituação, até o fato de que os padrões dos discursos proferidos são distintos devido a construções socioculturais particulares.

Se isso é verdade entre países que integram o Sul Global, se verifica com ainda mais força quando estes são comparados com países do Norte Global, como Estados Unidos e países europeus. É comum que doutrina e jurisprudência analisem nossos problemas como se fossem os mesmos enfrentados por países desenvolvidos e por democracias estabelecidas há mais tempo e, assim, repliquem a solução por eles adotada, ignorando nossas particularidades. Contudo, a existência de diferenças de países do Sul entre si não impede que seja feita uma comparação, já que eles possuem realidades similares. Afinal, nossa análise e a própria definição da ideia de Sul Global partem de um ponto comum: tratam-se de países periféricos, em desenvolvimento e com desigualdades profundas e multidimensionais. A comparação restrita a eles, assim, mostra-se frutífera, pois existe considerável semelhança, o que permite uma interlocução mais natural das ideias constitucionais.

Nesses países, poucas são as pessoas com acesso à justiça e, em geral, as classes sociais menos favorecidas economicamente e os grupos vulneráveis e minoritários sob a ótica política são os que mais sofrem com essa realidade. A extrema desigualdade socioeconômica "causa a invisibilidade daqueles submetidos à pobreza extrema, a demonização daqueles que desafiam o sistema e a imunidade dos privilegiados, minando a imparcialidade da lei" ${ }^{\prime 12}$. Com isso, o estado de direito fica enfraquecido, e o sistema que deveria tomar a proteção e a garantia dos direitos fundamentais como seu ponto de partida e ponto de chegada ${ }^{113}$, acaba por violá-los.

Apesar disso, cada país tem lidado à sua maneira com o discurso de ódio. Não consideramos razoável afirmar que há um modelo ideal no combate à discriminação e no tratamento dessas manifestações: cada sociedade tem erros e acertos em diferentes campos e as soluções

\footnotetext{
112 VIEIRA, Oscar Vilhena. A desigualdade e a subversão do estado de direito. SUR - Revista Internacional de Direitos Humanos, n 6, ano 4, p. 42, 2007.

113 Ponto de partida pois os direitos fundamentais devem ser a fundamentação do Estado. Ponto de chegada pois a promoção e efetivação desses direitos deve ser sempre o objetivo estatal. NOVAIS, Jorge Reis. Contributo para uma Teoria do Estado de Direito: do Estado de Direito liberal ao Estado Social e Democrático de Direito. Coimbra: Almedina, 1987, p. 16-17.
} 
devem ser adaptadas de acordo com as particularidades locais, de modo que não é possível eleger um modelo como solução universal a ser seguida pelos demais. Contudo, no contexto político em que as palavras são esvaziadas de seu sentido original e as manifestações de ódio e violência são banalizadas ${ }^{114}$ - o que se soma ao desigual acesso à justiça, ao baixo número de denúncias e ao seu desestímulo -, é válido discutir as medidas que têm se mostrado efetivas.

Por exemplo, na Índia, como visto, existem apenas proibições abstratas, com vasta legislação vedando o incitamento ao ódio, mas os dados mostram que as manifestações discriminatórias aumentaram na última década. De outro lado, o México tem uma série de políticas públicas com o intuito de educar a população para a não discriminação, mas as pesquisas ainda apontam um cenário social de intolerância e a impermeabilidade da Corte para as minorias vulneráveis.

De qualquer modo, podemos notar que os modelos que conjugam medidas repressivas com medidas alternativas tendem a demonstrar maior sucesso. Nessa perspectiva, destaca-se o uso de comissões nacionais de prevenção à discriminação com atuação voltada para criação de planos de combate a essas condutas; estímulo de propagandas comunicativas para construção de uma cultura pluralista e não discriminatória; estudos relatando as estatísticas e causas dos crimes de ódio; cortes de igualdade, isto é, cortes especializadas para conflitos relacionados às minorias; observatórios de rádio, televisão e internet voltados para análise de produção de conteúdo discriminatório e elaboração de recomendações, entre outras possibilidades. As respostas às manifestações de ódio devem estabelecer um diálogo positivo não apenas com as vítimas, mas também com os próprios ofensores.

Nesse sentido, é interessante observar a abordagem de Martha Minow ${ }^{115}$, que pode ser aplicada ao discurso

\footnotetext{
114 Sobre a ideia de banalização do mal, cf. ARENDT, Hannah. Eichmann em Jerusalém: Um relato sobre a banalidade do mal. Tradução de José Rubens Siqueira. São Paulo: Companhia das letras, 1999.

115 Cf. o livro da autora (MINOW, Martha. When should law forgive? New York: W. W. Norton \& Company, 2019), a esclarecedora entrevista concedida ao jornal The New Yorker (CHOTINER, Isaac. The Laws of Forgiveness. The New Yorker, nov. 2019. Disponível em: <https://www.newyorker.com/news/q-and-a/the-laws-offorgiveness $>$. Acesso em: 20 dez. 2020), e o debate feito na Universidade de Harvard (NEAL, Jeff. Forgiveness in an age of 'justified resentments'. Harvard Law Today, nov. 2019. Disponível em:
}

de ódio. A autora parte da constatação de que vivemos a época de maior encarceramento na história da humanidade e que estamos na era do ressentimento, intensificada por acontecimentos como a crise financeira de 2008 e as divisões sociais derivadas de desigualdades. Assim, defende a adoção, pelo Direito, de medidas alternativas ao punitivismo, voltadas para a concessão de perdão no plano social. Não se trata de pressionar vítima e agressor ao entendimento comum e ao reconhecimento de perdão, mas criar espaços de diálogos para que possam existir conversas de justiça restaurativa. Isso não significa ignorar o que aconteceu, mas respeitar o devido processo legal, bem como adotar técnicas de atribuição de responsabilidade e afins.

A previsão dessas medidas alternativas de combate ao discurso de ódio tende a criar um ambiente de diálogo e desenvolvimento de um pacto coletivo de valorização do pluralismo e da não discriminação. Todas essas medidas devem ser conjugadas com um trabalho de promoção da deliberação democrática e do acesso à justiça e aos canais públicos de solução de conflitos. Assim, da mesma forma que se assegura a proteção da liberdade de expressão e evita-se sua supressão, também se impede a violação da dignidade humana e dos direitos fundamentais dos grupos alvo, tradicionalmente marginalizados.

\section{Considerações finais}

O presente estudo buscou realizar uma análise comparada sobre o tratamento do discurso de ódio em cinco países do Sul Global. Por serem países com histórias e realidades semelhantes, o cotejo entre seus ordenamentos e suas experiências se mostra mais frutífero do que os exames tradicionalmente feitos, que comparam países do Sul com os do Norte Global. Como visto, o tratamento varia entre os modelos repressivos e alternativos. No primeiro caso temos Colômbia e Índia. No segundo, África do Sul, Argentina e México. Os modelos alternativos, que conjugam proibições abstratas do discurso de ódio com políticas públicas de conscientização e combate de práticas discriminatórias, se mostram mais efetivos. Em um contexto de assimetria no acesso à justiça, intenso histórico de discriminação, desrespei-

$<$ https://today.law.harvard.edu/forgiveness-in-an-age-of-justifiedresentments $>$. Acesso em: $20 \mathrm{dez}$. 2020). 
to aos direitos fundamentais e desigualdades políticas e socioeconômicas, é importante, para além da proibição penal de práticas que contrariem a Constituição, criar um ambiente de diálogo e ampliar o acordo social de respeito à diversidade. Concomitantemente, é essencial expandir o acesso à justiça e os canais públicos de solução de conflitos.

\section{Referências}

AMERSFOORT, Hans van. 'Minority' as a sociological concept. Ethnic and Racial Studies, v. 1, n. 2, p. 218234, 1978.

ANDERSON, Judith M. A million little ways: racism and everyday performances of blackness in Buenos Aires. African and Black Diaspora: An International Journal, v. 7, n. 2, p. 165-176, 2014.

ARENDT, Hannah. Eichmann em Jerusalém: Um relato sobre a banalidade do mal. Tradução de José Rubens Siqueira. São Paulo: Companhia das letras, 1999.

ARTICLE 19. Responding to 'hate speech': Comparative overview of six EU countries. London: Article 19, 2018.

ATTAQUES CONTRE DES lieux de culte: le chef de l'ONU appelle à lutter contre l'intolérance et la haine. ONU Info, abr. 2019. Disponível em: <https://news. un.org/fr/story/2019/04/1042221>. Acesso em: 11 jun. 2020.

BELAVUSAU, Uladzislau. Hate Speech. In: Max Planck Encyclopedia of Comparative Constitutional Law [MPECCoL], 2017. Disponível em: < https:/ / oxcon.ouplaw.com/view/10.1093/law-mpeccol/lawmpeccol-e130?prd=MPECCOL $>$. Acesso em: 07 jan. 2020 .

BERTONI, Eduardo. Estudio sobre la prohibición de la incitación al odio en las Américas. OHCHR, [s.d.]. Disponível em: <https://www.ohchr.org/Documents / Issues/Expression/ICCPR/Santiago/SantiagoStudy_ sp.pdf>. Acesso em: 20 dez. 2019.

BOBBIO, Norberto. A natureza do preconceito. In: Elogio da serenidade: e outros escritos morais. Tradução de Marco Aurélio Nogueira. 2. ed. São Paulo: Editora Unesp, 2011, p. 103-118.

BOROOAH, Vani K. Caste, Inequality, and Poverty in
India. Review of Development Economics, v. 9, n. 3, p. 399-414, 2005.

BOSCH, Tanja. Twitter activism and youth in South Africa: the case of \#RhodesMustFall. Information, Communication \& Society, v. 20, n. 2, p. 1-12, 2016.

CASTELLS, Manuel. Rupture: the crisis of liberal democracy. Cambridge, UK: Polity Press, 2018.

CASTILLO, S. S.; ABRIL, N. G. P. Discourse and racism in Colombia: five centuries of invisibility and exclusion. In: DIJK, Teun A. van (Ed.). Racism and Discourse in Latin America. New York: Lexington Books, 2009, p. 131-170.

CHOTINER, Isaac. The Laws of Forgiveness. The New Yorker, nov. 2019. Disponível em: <https:// www.newyorker.com/news/q-and-a/the-laws-of-forgiveness>. Acesso em: 20 dez. 2020.

CHOUDHRY, Sujit (Ed.). The migration of constitutional ideas. Cambridge: Cambridge University Press, 2006.

COMISIÓN ECONÓMICA PARA AMÉRICA LATINA Y EL CARIBE. Panorama Social de América Latina. Santiago: Naciones Unidas, 2019.

COMMITTEE ON THE ELIMINATION OF RACIAL DISCRIMINATION (CERD). Concluding observations on the combined eighteenth to twenty-first periodic reports of Mexico, [S.1], 19 de set. de 2019.

COURTIS, Corina et al. Racism and discourse: a portrait of the argentine situation. In: DIJK, Teun A. van (Ed.). Racism and Discourse in Latin America. New York: Lexington Books, 2009, p. 13-56.

DANE - Información para todos. Boletín técnico de pobreza monetária na Colômbia 2018. Bogotá, maio 2019.

DANIYAL, Shoaib. In-depth: How a Facebook post broke the decades-long communal peace of a West Bengal town. Scroll.in, jul. 2017. Disponível em: < https:/ / scroll.in/article/843692/in-depth-how-a-facebookpost-broke-the-decades-long-communal-peace-of-awest-bengal-town>. Acesso em: 03 nov. 2019.

DESHPANDE, Ashwini. The Grammar of Caste: Economic discrimination in contermporary India. Oxford: Oxford University Press, 2011.

DEVOTO, Fernando. Historia de la Inmigración en 
Argentina. Buenos Aires: Sudamericana, 2002.

DIAMOND, Larry. Facing Up to the Democratic Recession. Journal of Democracy, Whashington, v. 26, n.1, p. 141-155, jan. 2015.

DIJK, Teun A. van. Racism and discourse in Spain an Latin America. Amsterdam/Philadelphia: John BenjaminsPublishing Company, 2005.

DUBOW, Saul. Apartheid, 1948-1994. Oxford: Oxford University Press, 2014.

DWORKIN, Ronald. Foreword. In: HARE, Ivan; WEINSTEIN, James (Eds.). Extreme Speech and Democracy. New York: Oxford University Press, 2009, p. v-ix.

EMBREE, Ainslie T. Utopias in conflit: religion and nationalism in modern India. Berkley: University of California Press, 2018.

FEINSTEIN, Charles H. An Economic History of South Africa. Conquest, discrimination and development. Cambridge: Cambridge University Press, 2005.

FRANKENBERG, Günter (Ed.). Order from transfer: comparative constitutional design and legal culture. Cheltenham, UK; Northampton, MA, USA: Edward Elgar, 2013.

FRANKENBERG, Günter. Constitutional transfer: the IKEA theory revisited. I-CON, v. 8, n. 3, p. 563-579, 2010.

FREIRE, Alonso Reis Siqueira. A comparação no direito constitucional: metodologias, abordagens, tipos de pesquisa e princípios de inferência orientada para pesquisas small- $n$. 2014. 52f. Universidade do Estado do Rio de Janeiro, Rio de Janeiro, 2014, mimeo.

FUZIGER, Rodrigo. Margeando o Estige: o direito penal e a limitação dos crimes de ódio relacionados à religião. Revista General de Derecho Penal, Madri, v. 19, p. 1-22, 2013.

G1. Ataques a duas mesquitas deixam 50 mortos na Nova Zelândia. G1, mar. 2019. Disponível em: < https:/ / g1.globo.com/mundo/noticia/2019/03/14/policia-eacionada-apos-relatos-de-tiros-em-mesquita-na-novazelandia.ghtml>https://g1.globo.com/google/amp/ mundo/noticia/2019/03/14/policia-e-acionada-aposrelatos-de-tiros-em-mesquita-na-nova-zelandia.ghtml. Acesso em: 10 jan. 2020.
GRIMSON, Alejandro; KESSLER, Gabriel. On Argentina and the Southern Cone: Neoliberlism and National Imaginations. New York; London: Routledge, 2005.

GUERREROS, A. C.; IZQUIERDO, J. G.; PINEDA, F. Racist discourse in Mexico. In: DIJK, Teun A. van (Ed.). Racism and Discourse in Latin America. New York: Lexington Books, 2009, p. 217-258.

HERNÁNDEZ, Tanya Katerí. Subordinação racial no Brasil e na América Latina: o papel do Estado, o Direito Costumeiro e a Nova Resposta dos Direitos Civis. Trad. de Arivaldo Santos de Souza e Luciana Carvalho Fonseca. Salvador: EDUFBA, 2017.

HERZ, Michael; MOLNAR, Peter. The Content and Context of Hate Speech: Rethinking Regulation and Responses. Cambridge: Cambridge University Press, 2012.

HIRSCHL, Ran. Comparative Matters: The Renaisssance of Comparative Constitutional Law. Oxford: Oxford University Press, 2014.

HUMAN RIGHTS COUNCIL. Report of the independent expert on minority issues, Gay McDougall: Mission to Colombia. [S.1], jan. 2011.

HUMAN RIGHTS COUNCIL. Report of the Special Rapporteur on contemporary forms of racism, racial discrimination, xenophobia and related intolerance. A/HRC/38/52. [s.l.], abr. 2018. Disponível em: $\quad<$ https://documents-dds-ny.un.org/doc/UNDOC/GEN/G18/117/79/PDF/G1811779.pdf>. Acesso em: 11 jun. 2020.

HUMAN RIGHTS WATCH. Violent Cow Protection in India: Vigilante Groups Attack Minorities. [S.1]: Human Rights Watch, 2019.

INEGI. Encuesta Nacional sobre Discriminación (ENADIS), [S.1]: INEGI, 2017.

ISAACK, Wendy. South African Move on Hate Speech a Step Too Far. Human Rights Watch, fev. 2017. Disponível em: <https://www.hrw.org/ news/2017/02/21/south-african-move-hate-speechstep-too-far>. Acesso em: 02 jun. 2020.

JACKSON, Vicki C. Comparative Constitutional Law: Methodologies. In: ROSENFELD, Michel; SAJÓ, András (eds.). The Oxford Handbook of Constitutio- 
nal Comparative Law. Oxford: Oxford University Press, 2012.

KILLIAN, L. M. What or who is a "minority"? Michigan Sociological Review, v. 10, p. 18-31, 1996.

KIRCHNER, Stefan. Outlawing hate speech in democratic States: the case against the inherent limitations doctrine concerning Article 10 (1) of the European Convention on Human Rights. Revista de Direito Internacional, Brasília, v. 12, n. 1, p. 415-423, 2015.

KOATZ, Rafael Lorenzo-Fernandez. A Liberdade de Expressão e o Discurso de Incitação ao ódio (Hate Speech). 2007. Dissertação (Mestrado em Direito Público) - Universidade do Estado do Rio de Janeiro, Rio de Janeiro, 2007.

KOMMERS, Donald P. The Value of Comparative Constitutional Law. John Marshall Journal of Practice and Procedure, Chicago, v. 9, p. 685-695, 1976.

LANZA, André Luiz; LAMOUNIER, Maria Lucia. A América Latina como Destino dos Imigrantes: Brasil e Argentina (1870-1930). Cadernos Prolam/USP, v. 14, n. 26 , p. $90-107,2015$.

LEVITSKY, Steven; ZIBLAT'T, Daniel. How democracies die. New York: Crown, 2018.

LEWIS, Anthony. Freedom for the Thought That We Hate: a Biography of the First Amendment. New York: Basic Books, 2008.

LUTTE CONTRE LA haine, la discrimination, le racisme et l'antisémitisme. Ministère de L'Intérieur, feb. 2019. Disponível em: <https://www.interieur.gouv.fr/ Actualites /Communiques/Lutte-contre-la-haine-ladiscrimination-le-racisme-et-l-antisemitisme $>$. Acesso em: 11 jun. 2020.

MACHADO, Jónatas Eduardo Mendes. Liberdade de expressão: dimensões constitucionais da esfera pública no sistema social. Coimbra: Coimbra Editora, 2002.

MACHADO, Natália Paes Leme. A "plena" liberdade de expressão e os direitos humanos: análise da jurisprudência da corte interamericana de direitos humanos e o julgamento da ADPF 130. Revista de Direito Internacional, Brasília, v. 10, n. 2, p. 280-296, 2013.

MELLO, Patrícia Perrone Campos. Precedentes vinculantes nos Estados Unidos da América e no direito brasileiro: um estudo comparado. Revista de Direito Internacional, Brasília, v. 13, n. 3, p. 263-285, 2016.
MINOW, Martha. When should law forgive? New York: W. W. Norton \& Company, 2019.

MORIN, E. Para um pensamento do sul. In: Para um pensamento do sul: diálogos com Edgar Morin. Rio de Janeiro: SESC, Dep. Nacional, 2011, p. 8-21.

NACIONES UNIDAS. Informe del Alto Comisionado de las Naciones Unidas para los Derechos Humanos sobre la situación de Derechos Humanos en Colombia durante el año 2018 (A/ HRC/40/3/Add.3). 2019. Disponível em: <https:// www.hchr.org.co/index.php/informes-y-documentos/ informes-anuales/9017-informe-del-alto-comisionadode-las-naciones-unidas-para-los-derechos-humanossobre-la-situacion-de-derechos-humanos-en-colombiadurante-el-ano-2018>. Acesso em: 20 jan. 2020.

NEAL, Jeff. Forgiveness in an age of 'justified resentments'. Harvard Law Today, nov. 2019. Disponível em: <https://today.law.harvard.edu/forgiveness-in-an-age-of-justified-resentments/>. Acesso em: 20 dez. 2020.

NORDLING, Linda. Racism rife at top South African university, says report. Nature, abr. 2019. Disponível em: <https://www.nature.com/articles/d41586-01901129-2>. Acesso em: 12 jun. 2020.

NOVAIS, Jorge Reis. Contributo para uma Teoria do Estado de Direito: do Estado de Direito liberal ao Estado Social e Democrático de Direito. Coimbra: Almedina, 1987.

OMMATI, José Emílio Medauar. Liberdade de expressão e discurso de ódio na Constituição de 1988. 4. ed. Rio de Janeiro: Jumen Juris, 2019.

PEOPLE DON'T UNDERSTAND freedom of speech: Gareth Cliff. Businesstech, 30 jan. 2016. Disponível em: <https://businesstech.co.za/news/ media/110791/people-dont-understand-freedom-ofspeech-gareth-cliff/>. Acesso em: 03 nov. 2019.

PEREIRA, Jane Reis Gonçalves. Classificação indicativa e vinculação de horários na programação de TV: a força das imagens e o poder das palavras. Revista da Seção Judiciária do Rio de Janeiro, v. 20, p. 169-197, 2013.

Interpretação Constitucional e Direitos Fundamentais. 2. ed. São Paulo: Saraiva, 2018.

PEREIRA, Néli. Redes sociais validam o ódio das pessoas, diz psicanalista. BBC Brasil, São Paulo, 10 de 
jan. de 2017. Disponível em: <https://www.bbc.com/ portuguese/brasil-38563773>https://www.bbc.com/ portuguese/brasil-38563773. Acesso em: 03 de set. de 2019.

PIZARRO, Jorge Martínez (Ed.). América Latina y el Caribe: migración internacional, derechos humanos y desarrollo. Santiago de Chile: CEPAL, 2008.

POU GIMÉNEZ, Francisca. Libertad de expresión y discurso homofóbico en México: ¿Es correcta la teoría constitucional de la Suprema Corte? Boletín Mexicano de Derecho Comparado, v. 47, n. 140, p. 585-616, maio/ago. 2014

RODRÍGUEZ-GARAVITO, C.; SIERRA, T. A.; ADARVE, I. C. (Coords.). Racial Discrimination and Human Rights in Colombia: A Report on the Situation of the Rights of Afro-Colombians. Bogotá: Universidad de Los Andes, Facultad de Derecho, CIJUS, Ediciones Uniandes, 2008.

ROSA, Marcelo. Sociologias do Sul: ensaio bibliográfico sobre limites e perspectivas de um campo emergente. Civitas: Revista das Ciências Sociais, Porto Alegre, v. 14, n. 1, p. 43-65, jan./abr. 2014.

ROSENFELD, Michel. Hate speech in constitutional jurisprudence: a comparative analysis. Cardozo Law School, working paper series n. 41, p. 4, 2001. Disponível em: <http://papers.ssrn.com/paper. taf?abstract_id=265939>. Acesso em: 8 jan. 2020.

RUNCIMAN, David. How Democracy Ends. Nova York: Basic Books, 2018.

SALDANHA, Alison. 2017: A year of hate crimes in India: Number of violent incidents related to cows, religion is rising. Firstpost, 28 de dez. de 2017. Disponível em: <https://www.firstpost.com/india/2017a-year-of-hate-crimes-in-india-number-of-violent-incidents-related-to-cows-religion-is-rising-4278751. html>https://www.firstpost.com/india/2017-a-yearof-hate-crimesin-india-number-of-violent-incidentsrelated-to-cows-religion-is-rising-4278751.html. Acesso em: 06 de set. de 2019.

SANTOS, Boaventura de Sousa. Para além do pensamento abissal: das linhas globais a uma ecologia dos saberes. Novos Estudos CEBRAP, São Paulo, n. 79, p. 71-94, nov. 2007.

SANTOS, Boaventura de Sousa; MENESES, Maria Paula. Introdução. In: (Orgs.). Episte- mologias do Sul. Coimbra: Almedina, 2009.

SARMENTO, Daniel. A Liberdade de Expressão e o Problema do 'Hate Speech'. Revista de Direito do Estado, Rio de Janeiro, v. 4, p. 53-106, out./dez. 2006.

Liberdade de expressão, pluralismo e o papel promocional do Estado. Revista Diálogo Jurídico, Salvador, n. 16, maio/ago. 2007.

SCHAUER, Frederick. Free speech: a philosophical enquiry. New York: Cambridge University Press, 1982.

SEEKINGS, Jeremy. The continuing salience of race: Discrimination and diversity in South Africa. Journal of Contemporary African Studies, v. 26, n. 1, p. 1-25, jan. 2008.

SIEMS, Mathias. Comparative Law. Cambridge: Cambridge University Press, 2014.

SORAL, Wiktor; BILEWICZ, Michał; Winiewski, Mikołaj. Exposure to hate speech increases prejudice through desensitization. Aggresive Behavior, p 1-11, 2017.

STANDARD BANK'S CHRIS Hart resigns after racista Twitter row. News24, Cidade do Cabo, mar. 2016. Disponível em: <https://www.news24.com/SouthAfrica/News/standard-banks-chris-hart-resigns-after-racist-twitter-row-20160314>. Acesso em: 02 nov. 2019.

SUNSTEIN, Cass R. \#Republic: Divided Democracy in the Age of Social Media. Princeton: Princeton University Press, 2017.

TAVARES, André Ramos. O direito fundamental ao discurso religioso: divulgação da fé, proselitismo e evangelização. Revista Brasileira de Estudos Constitucionais, Belo Horizonte, v. 3, n. 10, p. 17-47, abr./jun. 2009.

UNITED NATIONS HUMAN RIGHTS OFFICE OF THE HIGH COMMISSIONER. Report of the Special Rapporteur on contemporary forms of racism, racial discrimination, xenophobia and related intolerance on his mission to Argentina, [S.l], abr. 2017. Disponível em: <https://ap.ohchr.org/documents/dpage_e.aspx?si=A/HRC/35/41/Add.1>. Acesso em: 02 nov. 2019.

VIEIRA, Oscar Vilhena. A desigualdade e a subversão do estado de direito. SUR - Revista Internacional de Direitos Humanos, n 6, ano 4, p. 28-51, 2007.

VOS, Pierre De. Hate speech Bill could be used to silence 
free speech. Daily Maverick, fev. 2019. Disponível em: $<$ https://www.dailymaverick.co.za/opinionista/201902-26-hate-speech-bill-could-be-used-to-silence-freespeech/>. Acesso em: 02 jun. 2020.

WALDRON, Jeremy. The harm in hate speech. Cambridge, MA: Harvard University Press, 2012.

WIRTH, Louis. The problem of minority groups. In: LINTON, R. (Ed.). The science of man in the world crisis. New York: Columbia University Press, p. 347372.

YADAV, Anandita. Countering Hate Speech In India: Looking For Answers Beyond The Law. ILI Law Review, Nova Delhi, v. II, n. 6, Winter Issue 2018.

\section{Agradecimentos}

Agradecemos à FAPERJ pelo financiamento que contribuiu para o desenvolvimento desta pesquisa. 
Para publicar na Revista de Direito Internacional, acesse o endereço eletrônico www.rdi.uniceub.br ou www.brazilianjournal.org.

Observe as normas de publicação, para facilitar e agilizar o trabalho de edição. 